University of Miami Law School University of Miami School of Law Institutional Repository

2011

\title{
Procedural Protection of Constitutional Rights in Brazil
}

Keith S. Rosenn

University of Miami School of Law, krosenn@law.miami.edu

Follow this and additional works at: https://repository.law.miami.edu/fac_articles

Part of the Comparative and Foreign Law Commons

\section{Recommended Citation}

Keith S. Rosenn, Procedural Protection of Constitutional Rights in Brazil, 59 Am. J. Comp. L. 1009 (2011).

This Article is brought to you for free and open access by the Faculty and Deans at University of Miami School of Law Institutional Repository. It has been accepted for inclusion in Articles by an authorized administrator of University of Miami School of Law Institutional Repository. For more information, please contact library@law.miami.edu. 


\section{KEITH S. ROSENN*}

\section{Procedural Protection of Constitutional Rights in Brazil $\dagger$}

Brazil has developed one of the most complex systems of judicial review in the world. In addition, it has developed a wide variety of constitutional actions for the purpose of protecting the huge number of constitutional rights conferred by its lengthy Constitution. In theory, constitutional rights can be protected in ordinary actions. Because ordinary actions typically take a great many years to resolve in Brazil, the framers of the 1988 Constitution, building on Brazil's prior constitutions and foreign models, constitutionalized a wide array of procedural devices to try to assure that the huge number of individual, social and economic rights created by the current Constitution are effectively protected by the judiciary. This Article explores the complexities of these constitutional procedures, how they have worked or not worked in practice, and the problems that they have created for the Brazilian Judiciary.

\section{INTRODUCTION}

Gaps between the law on the books and the law in action are evident in all societies. In Latin America, particularly in the area of constitutional law, that gap has loomed particularly large. Noting that between independence and 1959, Latin American republics had adopted a total of 186 constitutions, one scholar observed: "Nowhere are constitutions more elaborate and less observed."1 More recently, Miguel Schor stated: "Constitutional law in Latin America has an almost surreal quality ...."2 Many factors help explain why it has been so difficult to implant successful constitutionalism in Latin America. ${ }^{3}$ One factor has been the region's slowness to develop effective proce-

\footnotetext{
* Professor of Law, University of Miami School of Law.

$\dagger$ DOI 10.5131/AJCL.2010.0033

1. J. Lloyd Mecham, Latin American Constitutions-Nominal and Real, $21 \mathrm{~J}$. Politics 258 (1959).

2. Miguel Schor, Constitutionalism Through the Looking Glass of Latin America, 41 Tex. INT'L L. J. 1, 5 (2006).

3. These many factors are explored in Keith S. Rosenn, The Success of Constitutionalism in the United States and Its Failure in Latin America: An Explanation, 22 U. MiAmi InTER-AM. L. REv. 1, 20-30 (1990); Schor, supra note 2, at 14-35.
} 
dural devices for ensuring compliance with constitutional guarantees. The framers of the nineteenth century Latin American constitutions, influenced by the French Declaration of the Rights of Man, explicitly set forth essential human rights. Their hope was that if fundamental rights were listed in the constitution, both the government and the people would naturally respect those rights. ${ }^{4}$ After it became apparent that constitutional rights were being honored only in the breach, certain Latin American jurists realized that they needed to borrow or create speedy procedural remedies because ordinary judicial remedies, which required protracted litigation, were ineffective to protect fundamental rights.

In 1830, while still a constitutional monarchy, Brazil became the first Latin American country to adopt the Anglo-American institution of habeas corpus. Since then, Brazil has gradually created a panoply of special procedural institutions for the protection of constitutional rights. Brazil's current Constitution, adopted in 1988 as a reaction to twenty-one years of military dictatorship during which constitutional rights were widely disrespected, explicitly guarantees a vast number of individual, social, and economic rights. It also constitutionalizes many rules of private and administrative law, particularly in the area of labor law, tax law, foreign investment, and social security. The Constitution contains a great many programmatic norms that require enactment of complementary legislation for their implementation. In a bold attempt to assure that these constitutional rights do not exist solely on paper, as had been the case under prior constitutions, the framers created a broad array of constitutionalized procedural devices to enable individual litigants, certain elected officials, and a variety of civic and political organizations to try to secure effective judicial protection of these rights. While these procedural mechanisms have significantly improved protection of constitutional rights, a substantial gap between important rights on paper and in practice persists.

Brazil's 1988 Constitution has established an extensive and complicated system of judicial review. It is a hybrid system, combining a decentralized, incidental form of judicial review modeled after the United States with a centralized, abstract form of judicial review modeled after that of European countries like Germany and Italy. The constitutionality of any federal, state, or municipal law or decree may be challenged incidentally in ordinary litigation before any state or federal court. ${ }^{5} \mathrm{~A}$ constitutional issue can be raised by any party

4. Heitor Fix Zamudio, Latin American Procedures for the Protection of the Individual, 9 J. INT'L CoMm'N JuRISTS 60-61 (Dec. 1968).

5. Although Article 97 of the 1988 Brazilian Constitution provides that tribunals may declare laws or normative acts unconstitutional only by an absolute majority vote of their members, a provision that has been in Brazilian Constitutions since 1934 , the case law and doctrine agree that single judges may exercise the power of 
(including a third party), the Public Ministry, ${ }^{6}$ or even by the court itself. $^{7}$ Typically, a party raises a constitutional question in ordinary litigation by means of a pleading called an exception or by way of defense. Usually, a party does not attack the constitutionality of a law or decree directly. Instead, parties typically attack the constitutionality of an act or conduct based upon the offending law or decree. ${ }^{8}$ The Constitution also specifically confers standing upon a limited group of officials and organizations to challenge the constitutionality of any law or decree in the abstract in four different forms of actions that can be brought directly before the Supreme Federal Tribunal (STF), Brazil's highest court, or, in certain cases, before the Tribunals of Justice, the highest state courts. ${ }^{9}$ In addition, the constitutionality of proposed and enacted constitutional amendments can be challenged before the STF.10

judicial review. RE 89.553, Mar. 24, 1981 (STF 1st Chamber, Rep. Rafael Mayer), 97 R.T.J. 1191, 554 Rev. Trib. 253 (1981); Gilmar FERREIRA MENDES, InOCÊNCIA MÁrTIRES COELHO \& PAULO GUSTAVO GONET BRANCO, CURSO DE DIRETTO CONSTITUCIONAL 1068 (2d ed. 2008) [hereinafter MENDES ET AL.].

6. The Public Ministry is an autonomous civil law institution that has no real counterpart in common law countries. It combines aspects of the public prosecutor with responsibility for defending the legal order. It is headed by the Procurator General of the Republic, who sits with and renders his opinion to the Supreme Federal Tribunal but does not vote. The Public Ministry may intervene in all cases involving status of persons, guardianship, marriage, and any matter of public interest. He must render an opinion in cases involving abstract challengers to constitutionality and has standing to bring such actions. See BRAZILIAN Constitution of 1988, arts. 127-30 [hereinafter CoNST. OF 1988].

7. Clêmerson Merlin Clève, A fiscalizacação abstrata da constitucionalidade No DIREITO BRASILEIRo 98 (2d ed. 1999) [hereinafter ClÈVE]. Permitting the court to declare statutes unconstitutional sua sponte has little to commend it. The court does not have the benefit of briefing and argument by the parties and unnecessarily exercises the power of judicial review. Brazil has had at least one unfortunate experience with the STF resolving constitutional questions that are not raised by the case before it. In 1996, soon after Brazil adopted a badly needed comprehensive arbitration statute, Minister Sepúlveda Pertence, in a case involving recognition of a foreign arbitral award where both parties had specifically agreed to arbitrate after the dispute had arisen, used the occasion to declare unconstitutional sections of the Brazilian Arbitration Law that permitted enforcement of arbitration clauses agreeing in advance to arbitrate on the untenable theory that such clauses violate art. 5 (XXXV), which prohibits laws from excluding any injury or threat to a right from review by the Judiciary. Agravo Reg. Sentença Estrangeiro No. 5206-7, Oct. 10, 1996. See Arnoldo Wald, Patrick Schellenberg \& Keith S. Rosenn, Some Controversial Aspects of the New Brazilian Arbitration Law, 31 U. Miami InTER-Am. L. Rev. 223, 22829 (2000). Fortunately, his erudite but misguided decision was ultimately overturned by a majority of his colleagues. Judgment of Dec. 12, 2001, D.J.U. Apr. 30, 2004. In the five year interim, however, critical provisions of the new Arbitration Law were under a constitutional cloud.

8. CLÈVE, supra note 7, at 91-92.

9. Const. OF 1988, supra note 6, arts. 102 (I)(a), (q), and §1; art. 103. See ClèvE, supra note 7 , at $391-406$.

10. Art. $60 \S 4$ of the 1988 Brazilian Constitution expressly prohibits any constitutional amendment aimed at abolishing federalism, periodic elections, separation of powers, and individual rights and guarantees. The STF has permitted challenges to the constitutionality of proposed constitutional amendments by means of writs of security (see section IV infra), but has restricted standing only to members of Congress. 
As a general rule, lower court decisions on constitutional questions may be appealed all the way to the STF. The 1988 Constitution grants the STF jurisdiction to hear by extraordinary appeal (recurso extraordinário) any decision in sole or ultimate instance that is contrary to the Constitution, declares a treaty or federal law unconstitutional, or upholds a law or act of a local government against a constitutional challenge. ${ }^{11}$ The STF also has jurisdiction to hear ordinary appeals; all writs of habeas corpus, writs of security, habeas data, and mandates of injunction denied by superior tribunals; and cases involving political crimes. ${ }^{12}$ In addition, as will be seen in Sections IX to XII, the STF has original jurisdiction to decide four types of direct constitutional challenges, as well as a variety of other matters, such as trying ordinary criminal charges against members of Congress and a variety of other officials.

The STF's jurisdictional parameters are far too broad. Although it is meant to function primarily as a constitutional court, the STF is also forced to decide a great many non-constitutional matters, many of which involve trivial or frivolous claims or issues that it has already decided. ${ }^{13}$ It still lacks a procedural device similar to the U.S. Supreme Court's writ of certiorari that would enable the STF to pick and choose the cases that it wishes to hear or a true stare decisis doctrine that could eliminate relitigation of issues that the STF has already settled. As a result, its workload is overwhelming. In 1987, the year prior to adoption of the current Constitution, the STF decided 20,122 cases. Between 2000 and 2010, the STF decided an average of 110,720 cases per year.

There are only eleven ministers on the STF, and these caseloads would be impossible if the full Tribunal or even its five-member panels heard each case. The STF's statistics are somewhat misleading, however, because the great bulk of its cases are resolved by the decision of a single minister. A large number are dismissed by the President of the STF prior to distribution for lack of jurisdiction, un-

The cases are collected in Luís Roberto Barroso, O ConTrole de CONSTItucionALIDADE NO DIREITO BRASILEIRO 44-45, n.112 (2004). The STF has heard numerous challenges to promulgated constitutional amendments, almost always through direct actions of unconstitutionality. The cases are collected in MENDEs ET AL., supra note 5, at 1029, n. 128 .

11. Const. of 1988, supra note 6, art. 102 (III). The extraordinary appeal stems from the writ of error in the U.S. Judiciary Act of 1789. It entered Brazilian law in Decree 848 of Oct. 24, 1890, which structured the federal judiciary. Since then, the extraordinary appeal has been incorporated into every subsequent Brazilian constitution. Ada Pellegrini Grinover, Antonio Magalhães Gomes Filho \& Antonio Scarance Fernandes, Recursos no processo penal 202 (7th ed. 2011) [hereinafter Grinover ET AL.].

12. Const. of 1988, supra note 6, at art. 102 (II).

13. In 1997, Sepúlveda Pertence, former President of the STF, stated that research indicated that ninety percent of the appeals to the STF raised issues that had already been decided by the STF. 1 Revista Consulex 10 (No. 3, Mar. 1997). 
timeliness, frivolity, or failure to present an issue of general repercussion. Cases that make it past this initial screening are randomly assigned to a single minister (member) who acts as the reporter (relator) and who is responsible for studying the file and analyzing the issues. ${ }^{14}$ The reporter has the authority, acting alone, to dismiss cases that clearly should not be heard or which present claims contrary to the STF's settled case law or súmula (a form of precedent discussed in Section VIII (4) infra). The reporter on his or her own also can reverse an appealed decision that is manifestly contrary to the STF's settled case law or sumula. ${ }^{15}$ Cases that survive this dual screening process are then submitted either to the full court or a panel, depending upon the type of case, accompanied by the reporter's written statement of the case and vote. While another minister can stop the proceedings by asking to review the file, this happens infrequently; generally, the other members of the full court or panel concur with the vote of the reporter. Thus, last year, only $2.45 \%$ (2,546 cases) of the STF's 103,806 decisions were rendered by the full tribunal, and only $8.46 \%$ (8,788 cases) were decided by one of the STF's two panels. The remaining $89 \%(92,472$ cases) were resolved by the unilateral decision of either the reporter or the president or vice-president of the STF. ${ }^{16}$

Efforts at judicial reform are underway in Brazil; they seek gradually to reduce the enormous caseloads of Brazil's highest courts. A 2004 constitutional amendment has authorized the STF to refuse to hear certain types of appeals because they lack general repercussions. The same amendment has conferred power on the STF to create binding precedent on constitutional issues. Even though these reforms do not go far enough, they are definitely improving the situation.

\section{Habeas Corpus}

The oldest and most basic procedural institution for the protection of constitutional rights is habeas corpus. Habeas corpus crept into Brazilian law through the back door of the Penal Code of 1830 , which criminalized failure to issue or to delay issuance of writs of habeas corpus in cases in which they should have been granted or rearrested someone freed by habeas corpus, as well as the failure to comply with the writ or failure to help an official comply with the

14. Only in a few types of cases is a second member of the STF, called the reviewer, designated to assist the reporter and check his or her work. Reviewers are designated in rescissory actions, extraordinary criminal appeals, criminal revisions, original criminal actions, and declarations of suspension of rights. Regimento Interno do STF, art. 23.

15. Id., art. $21 \S \S 1$ and 2.

16. STF 2010 Relatório de Atividades, available at http://www.stf.jus.br/arquivo/ cms/sobreSTFConhecaSTFRelatorio/anexo/Relatorio2010.pdf. 
writ. ${ }^{17}$ The procedures governing issuance of the writ of habeas corpus were not actually regulated until promulgation of the Code of Criminal Procedure of $1832 . .^{18}$

The Brazilian writ of habeas corpus quickly grew to be far broader than its common law antecedent. Because it was the only summary procedure available to protect constitutional rights, Brazilian jurists expanded habeas corpus to try to protect a variety of rights that had nothing to do with physical liberty. ${ }^{19}$ For example, habeas corpus was utilized to annul a legislative act that cancelled a student's matriculation in a public school. ${ }^{20}$ Because the Brazilian courts were overwhelmed with habeas corpus petitions, a constitutional amendment was adopted in 1926 that restricted the use of habeas corpus to actual or threatened interferences with one's "liberty of locomotion."21

Brazil's present Constitution guarantees that "habeas corpus shall be granted whenever a person suffers or is threatened with suffering violence or coercion in his freedom of movement through illegality or abuse of power."22 This guarantee should be read together with several other complementary constitutional guarantees:

(1) No one shall be arrested unless in flagrante delicto or by written and substantiated order of a competent judicial authority, except for a military offense or a specific military crime, as defined by law. ${ }^{23}$

(2) The arrest of any person and the place where he can be found shall be communicated immediately to the proper judge and to the arrested person's family or to a person designated by him. ${ }^{24}$

(3) Judicial authorities shall direct immediate release of those illegally arrested. ${ }^{25}$

17. Código Criminal do Império do Brasil, arts. 183-87 (1830).

18. Arts. 340-55. These provisions were added to by Law 2.033 of 1871

19. Phanor Eder, Habeas Corpus Disembodied: The Latin American Experience, in XXTH Century Comparative And Conflicts Law; Legal Essays In Honor Of Hessel E. YNTEMa 463, 465-69 (Kurt H. Nadelmann, Arthur T. von Mehren \& John N. Hazard eds., 1961).

20. GRINOVER ET AL., supra note 11, at 270.

21. Amendment of Sept. 3, 1926, replacing art. $72 \S 22$ of the 1891 Constitution, 47 REv. FOR. 620, 627 (1926).

22. Const. of 1988, supra note 6, art. 5 (LXVIII). This constitutes an individual guarantee that cannot be altered by a subsequent constitutional amendment. Id. at art. $60, \S 4$ (IV). The Constitution also provides that habeas corpus and habeas data proceedings, as provided by law, are free of charge. Id. at art. 5 (LXXVII). Art. 5 of the Law on Judicial Costs, Law No. 9.289 of July 4, 1996, reiterates that habeas corpus and habeas data proceedings are free.

23. Const. of 1988, supra note 6, art. 5(LXI).

24. Id. at art. 5(LXII).

25. Id. at art. 5(LXV). 
(4) No one shall be taken to prison or held therein when the law permits provisional liberty, with or without bond. ${ }^{26}$

The writ of habeas corpus has a very summary procedure and occupies the highest preference on courts' dockets. Because of the brevity of the procedure, habeas corpus cannot be utilized to determine controverted issues of fact, such as whether the accused's conduct constituted excusable behavior under the Penal Code or to determine which crime the prisoner should be charged with. ${ }^{27}$ There is no state action requirement for habeas corpus; it can be brought to challenge constraints on liberty from either public or private actors. ${ }^{28}$ Nor is there a statute of limitations for habeas corpus or res judicata estoppels. Habeas corpus will not lie, however, to challenge the legality of a sentence after it has been served or after the criminal sanction has been extinguished. ${ }^{29}$

Habeas corpus does not have its own regulatory statute; instead, it is governed by provisions of an obsolete Code of Criminal Procedure adopted during the Vargas dictatorship and misplaced under the general title of appeals. According to the statute, habeas corpus should be granted whenever an individual's liberty to come and go is constrained or imminently threatened with constraint by any state or private actor (1) without just cause, (2) when one is imprisoned for longer than permitted by law, (3) when the authority that ordered the constraint lacked jurisdiction to do so, (4) when the reason for the constraint has ceased, (5) when one is denied release on bail in cases where the law permits release, (6) when the proceedings are clearly null and void, or (7) when the offense is no longer punishable. ${ }^{30}$

Habeas corpus is one of the few constitutional actions in which third party standing is permitted. While it is normally brought by the individual whose liberty of movement is impaired or threatened with impairment, habeas corpus can be filed by any person, whether or not a lawyer, or by the Public Ministry, on behalf of another. ${ }^{31}$ Indeed, habeas corpus can even be granted ex officio. ${ }^{32}$ The Internal Rules of the STF provide that habeas corpus may not be conceded, however, if the petition is not authorized by the person whose liberty is affected. ${ }^{33}$

26. Id. at art. 5(LXVI).

27. Mendes ET Al., supra note 5, at 522.

28. GRINOVER ET AL., supra note 11, at 282-83.

29. STF, Súmula No. 695. The súmula is discussed infra in Section VIII.B. It is a black letter rule of law that need not but almost always is followed by all Brazilian courts.

30. Code of Criminal Procedure, Decree-Law No. 3.689 of Sept, 8, 1941, art. 648.

31. Id. at art. 654.

32. Id. at $654 \& 2$.

33. STF, Regimento Interno, art. 192, sole paragraph. 
In practice, habeas corpus is utilized much more broadly than the Code of Criminal Procedure indicates. Habeas corpus is routinely invoked to challenge the constitutionality of a criminal inquiry by a person required to testify, to challenge an indictment, to challenge a jury verdict or a criminal sentence. ${ }^{34}$ Moreover, habeas corpus can be employed as a means of protecting the right of a full defense in all criminal proceedings. ${ }^{35}$ For example, it can serve as a means of obtaining discovery in criminal cases. In a recent case involving its original jurisdiction, the STF issued a preliminary injunction in a habeas corpus proceeding ordering the release of secret wiretaps to the attorney of a member of Congress under criminal investigation so that his client could have the benefit of a full defense. ${ }^{36}$ Habeas corpus cannot, however, be used to challenge a criminal fine. ${ }^{37}$ Nor may it be used to challenge the legality of wiretapping or the breaking of bank secrecy unless the petitioner can show that the purpose of the disregard for privacy is to obtain evidence for a criminal prosecution..$^{38}$

Although the Code of Criminal Procedure is silent on the subject, habeas corpus can be utilized to attack the constitutionality of a law. The STF has construed its habeas corpus jurisdiction broadly, permitting habeas to be utilized to contest the constitutionality of a statute that actually had little to do with freedom of movement. In the case of Vieira Netto, ${ }^{39}$ the STF declared unconstitutional Article 48 of the National Security Law, which prevented anyone accused of a national security violation from working. In order to find that this was properly a case for habeas corpus, the STF held that the statute's prohibition on working constituted an interference with the rights of the petitioners, a group of bankers, businessmen, and a lawyer, to come and go to their offices. ${ }^{40}$ More recently, however, the STF has retreated from this strained interpretation, holding that the an indicted public official removed from his office by a decision of a Special

34. Mendes ET AL., supra note 5, at 522-23.

35. Laercio Pelligrino, O Habeas corpus: Teoria, prática, Jurisprudência IX (1990).

36. Benidito Dias de Carvalho, HC No. 88.520-9 Amapá, (STF en banc, Original Rep. Cármen Lúcia, Rep. for Decision, Marco Aurélio, Nov. 23, 2006).

37. STF, Súmula Nos. 693. Law No. 9.268 of 1996 amended Art. 51 of the Criminal Code to prohibit conversion of an unpaid fine into a prison sentence.

38. MENDES ET AL., supra note 5, at 524-25.

39. H.C. No. 45.232, Feb. $21,1968,44$ R.T .J. 322 (1968).

40. For a more recent decision in which the STF utilized a habeas corpus action to declare a statute unconstitutional, see Max Baumert Filho, H.C. No. 77724 (STF en banc, Nov. 4, 1998, Rep. Marco Aurélio). There are, however, decisions of lower courts holding that habeas corpus cannot be used to attack the constitutionality of a law because the procedure is too summary. E.g., Jurandyr Fonsi, HC No. 122.048, 469 Rev. Trib. 291 (Trib. Just. São Paulo, Feb. 12, 1974, Rel. Mendes França); H.C. No. 94116 , D.J. May 14, 1997, p. 9.378 (Trib. Just. D.F., Mar. 20, 1997, Rep. Lécio Resende), criticized as incorrect in Lenio LuIZ STRECK, JURISDIÇĀo ConstituTIONAL E HERMENÊUTICA 462-63 (2d ed. 2004). 
Organ of Brazil's second highest court, the Superior Tribunal of Justice (STJ), cannot use habeas corpus to challenge his removal because there was no interference with his liberty of locomotion. ${ }^{41}$

The Code of Criminal Procedure is also silent with respect to the right of the courts to issue a preliminary injunction in habeas corpus cases. Paradoxically, this lacuna was first filled by military tribunals at a time when Brazil was under military dictatorship. In 1964, the Superior Military Tribunal confirmed issuance of a preliminary injunction preventing a military officer from requiring a civilian to testify at a military inquiry on a subject that had nothing to do with the military. ${ }^{42}$ Soon thereafter, the STF began issuing preliminary injunctions in habeas corpus cases, ${ }^{43}$ and it is now common practice for Brazilian courts to do so. ${ }^{44}$

Despite Brazil's long established constitutional guarantee of habeas corpus, a great many prisoners remain confined in a hugely overcrowded and horrendous prison system ${ }^{45}$ when they should be at large. Pretrial detainees make up forty-four percent of Brazil's prison population of nearly 500,000 , one of the largest in the world. Brazil's badly overcrowded prisons would be much worse were it not for the failure to incarcerate an estimated 60,000 convicted fugitives from justice. ${ }^{46}$ In the past year, at the initiative of the National Council of Justice, groups of judges drawn from different areas were assembled to review the status of prisoners. Between August 2008 and the end of December 2010, the National Council of Justice announced that after reviewing 218,401 cases, these ad hoc groups of judges, called mutirões, had freed 27,791 wrongfully imprisoned detainees. In addition, the mutirões found that 49,586 prisoners were being held at inappropriate security levels. ${ }^{47}$

41. HC-AgRg 84.326/PE, Diário de Justiça of Oct. 1, 2004 (S'TF, Rep. Ellen Gracie); HC 84.816/PI, Diário de Justiça of May 6, 2005 (STF, Rep. Carlos Velloso).

42. The lawyer for the petitioner was Arnoldo Wald, one of Brazil's most distinguished jurists, and the case is set out in Arnoldo Wald, As Origens da Liminar em Habeas Corpus no Direito Brasileiro, 747 Rev. Trib. 803, 804-06 (1998).

43. Id. at 803,806 .

44. João Roberto Parizatto, Do Habeas corpus: Doutrina, prática forense e JURISPRUDENCIA 21-23 (1991); Gamil Föppel \& Rafael Santana, Habeas Corpus, in Açóes Constitucionais 27, 57-60 (Fredie Didier Jr. ed., 3d ed. 2008).

45. See Katherine Haas, Inhumane, Ineffective, Intolerable: Brazil's Prison System, Council on Hemispheric Affairs Research Memorandum No. 1, Aug. 26, 2010, at 1-2, available at www.coha.org/inhumane-ineffective-intolerable-brazil $\%$ e22\%80\%99 s-prison-system/ [hereinafter Haas Report].

46. Int'l Bar Assoc., Human Rts. Inst., One in Five: The Crisis in Brazil's Prisons and Criminal Justice System 16-17 (Feb. 2010) [hereinafter Int'l Bar Assoc. Report]. This estimate divides the total number of unserved sentences by five on the unverified assumption that each fugitive probably has about five unserved sentences. Id. at 17 .

47. Luiz Flávio Gomes \& Roberta Calix Coelho Costa, Justiça Criminal: Seletividade e Impunidade. Mutirões do CNJ Liberam 33 Presos por Dia, 16 Revista Jus NAvigand (Mar. 30, 2011), available at http://jus.uol.com.br/revista/texto/18789. 
These recent investigations reveal that roughly one-fifth of all pretrial detainees in Brazil are being wrongfully imprisoned despite the theoretical availability of habeas corpus. ${ }^{48}$ There are a number of reasons for this malfunction. Even though the Constitution guarantees the right to pretrial release when the law permits, ${ }^{49}$ in practice Brazilian judges overuse pretrial detention to try to combat the popular perception that the Judiciary is soft on crime and routinely releases common criminals. One study found that Brazilian judges routinely order pretrial detention for those accused of petty theft, even though this is a minor offense for which pretrial release is authorized. ${ }^{50}$ A second reason is that despite a constitutional right to counsel, ${ }^{51}$ the Public Defender's Office has neither the funding nor the staff to provide legal counsel for the vast numbers of accused persons who need legal assistance. ${ }^{52}$ According to a study conducted in the State of São Paulo in 1999-2000, defense lawyers never even sought pretrial release in ninety-eight percent of the cases in which their clients were arrested in flagrante delicto for robbery. ${ }^{53} \mathrm{~A}$ third reason is bureaucratic incompetence. Prisoners frequently become lost in the system, serving more time in pretrial detention than the maximum sentence if convicted, or having been convicted, serving more time than their sentences. ${ }^{54} \mathrm{~A}$ fourth reason is the staggering slowness of the Brazilian criminal justice system. The mutirões dis-

48. A year earlier, the Director of Brazil's Penitentiary System (DEPEN), Maurício Kuehne, estimated that about thirty percent of all Brazilian prisoners should be at liberty. CPI Sistema CarCERário 221 (Biblioteca Digital da Câmara dos Deputados, Centro de Documentação e Informação, 2009), available at http://bd.camara.gov.br. [hereinafter CPI CARCERARIO].

49. ConST. OF 1988, supra note 6, art. 5 (LXVI) provides: "No one shall be taken to prison or held therein when the law permits provisional liberty, with or without bond."

50. Int'l Bar Assoc. Report, supra note 46, at 8. A legislative inquiry into the prison system found that poor defendants routinely are sentenced to prison for theft of food or articles of clothing. Even though art. 5 (LXVII) of the 1988 Constitution prohibits civil imprisonment for debt, the CPI found one female prisoner in Porto Velho whom a civil judge had sentenced to prison for being two months behind on her rent. CPI CARCERARIO, supra note 48 , at 49,309 . The STJ recently released on habeas corpus a prisoner who had been sentenced to seven years of prison plus 319 fine-days for stealing three used undershorts and a pair of socks from a backyard. HC 201325, May 3, 2011 (STJ, 6th Chamber, Rep. OG Fernandes).

51. CoNST. OF 1988, supra note 6 , art. 5 (LXIII) provides: "One under arrest shall be informed of his rights, including the right to remain silent, and shall be assured assistance of his family and a lawyer."

52. Int'l Bar Assoc. Report, supra note 46, at 48-50; Haas Report, supra note 45, at $2-3$

53. Int'l Bar Assoc. Report, supra note 46, at 9.

54. The mutiroes found more than 250 cases in which prisoners were still imprisoned, some for more than four years, after having served their sentences. Conselho Nacional de Justiça, Relatório Anual 168 (2009) [hereafter CNJ Relatório 2009]. The STF recently issued a preliminary injunction in a habeas corpus appeal ordering the immediate release of a defendant who had been detained for more six-and-a-half years awaiting retrial after his conviction had been reversed on appeal. H.C. No. 106.435-MC São Paulo, Nov. 29, 2010 (STF, Rep. Min. Celso de Mello). 
covered detainees that had been confined as long as fourteen years awaiting trial, as well as detainees confined as long as three years simply waiting to be charged with an offense by the prosecutor. ${ }^{55}$

Habeas corpus is widely perceived as a privilege freely available to the rich and politically well connected. It is exceedingly rare for people who can afford a high powered lawyer to spend time in a Brazilian prison. The Brazilian Constitution provides, somewhat illogically, that "No one shall be considered guilty until his criminal conviction has become final and nonappealable." 56 When accused of crimes, the wealthy and the politically connected almost invariably manage to avoid pretrial detention. Brazilian law confers on a vast number of persons the right to avoid pretrial detention with common criminals. This privilege of special prison, often at one's own home, extends to all elected officials, members of the police and military, any criminal justice system employee, judges, prosecutors, diplomats, members of the antitrust board, members of the clergy, civil servants, those who have served on juries, pilots, firemen, directors and administrators of unions and business syndicates, elementary and secondary school teachers, and anyone with a university degree. ${ }^{57}$ Moreover, the right to special prison lasts until one's conviction becomes final and nonappealable. ${ }^{58}$ Wealthy defendants usually manage to manipulate the seriously overburdened criminal justice by filing dilatory motions that postpone trial for many years. If ultimately convicted, they appeal their convictions ad infinitum while at liberty. ${ }^{59}$ In the rare event that a judge orders their confinement, habeas corpus functions extremely well, perhaps too well, for the rich and the powerful. ${ }^{60}$

Members of Congress historically have had little need for habeas corpus because the Brazilian Constitution confers both the privilege

55. CNJ Relatório 2009, supra note 54, at 169.

56. Const. of 1988, supra note 6, art. 5(LVII).

57. Luís Fernando de Moraes Manzano, Curso de processo penal 434-37 (2010).

58. Id. at 434 .

59. CPI CARCERÁrio, supra note 48 , at $47-49$. For example, Regivaldo Pereira Galvão, one the of ranchers charged with ordering the assassination of the American nun, Dorothy Stang, in 2005 remained at liberty after securing a writ of habeas corpus until his eventual trial in 2010 . Shortly after conviction, he was again released upon habeas corpus pending the outcome of his appeal. The STF has been reversing the lower courts and releasing upon habeas corpus persons convicted of serious crimes like rape until the judgment becomes final and nonappealable. E.g., H.C. 91676/RJ, Rep. Ricardo Lewandowski, STF en banc, Dec. of Feb. 12, 2009, 31 LEX STF, no. 367, pp. 311-54 (2009).

60. One of the more recent notorious examples is that of Daniel Dantas, formerly President of Banco Opportunity, whose arrest on fraud charges was twice ordered by a federal judge in São Paulo in 2008. On each occasion, Dantas' attorneys bypassed the intermediate courts of appeal and obtained a writ of habeas corpus directly from the President of the Supreme Federal Tribunal. David Fleischer, Brazil, in CounTries AT tHe Crossroads 2010, at 13 (Freedom House, 2010), available at www.freedom house.org/uploads/ccr/country-7788-9.pdf. 
of parliamentary immunity ${ }^{61}$ and the right to be tried exclusively by the overburdened STF. ${ }^{62}$ Although criminal proceedings have been filed against 152 members of Congress, many of whom face multiple accusations and some of whom even have multiple convictions in state courts, ${ }^{63}$ between September 1988 and April 2010, the STF failed to convict any member of Congress. In a signal that the days of Congressional impunity may be numbered, between May and September 2010, the STF somehow found time to convict three members, although none was actually sentenced to serve hard jail time. ${ }^{64}$ Even more surprisingly, in October 2010, a panel of the STF convicted and sentenced Natan Donadon, a deputy from the State of Rodônia, to prison for a substantial term. ${ }^{65}$ Despite this conviction, Donadon is currently back in Congress. In December 2010, a member of the STF issued a preliminary injunction overriding a decision of the Superior Electoral Tribunal and allowing Donadon to retake his seat in Congress pending the outcome of his request for clarification of the STF's decision that convicted him. ${ }^{66}$

61. From the date of investiture, members of Congress may not be arrested except in flagrante delicto for a non-bailable crime, in which case the respective chamber decides whether the accused should be imprisoned. Const. of 1988, supra note 6, art. $53 \S 2$. If a member of Congress is accused of a crime after investiture, the respective chamber may suspend the criminal proceedings any time prior to a final decision. Id. at art. $53 \S 3$.

62. Id. at art. $53 \S 1$. This provision makes no practical sense. With an annual caseload exceeding 100,000 , the STF is institutionally incapable of functioning as a trial court.

63. For a list of all charges against Congressional members from STF records as of May 20, 2010, see "A Lista dos Parlamentares Processados, por Estado," available at http://congressoemfoco.uol.com.br/noticia.asp?cod_canal=21\&cod_publicacao= 29847.

64. On May 13, 2010, José Gerado Arruda Filho became the first Congressman to be convicted by the STF, which sentenced him to two years and two months of community service. On May 20, 2010, Cássio Taniguchi became the second Congressman to be convicted by the STF for diverting funds from the Inter-American Development Bank when he was mayor of Curitiba. He was sentenced to six months in jail, but actually will serve no time because of the running of the limitations period. On September 27, 2010, Deputy José Fuscaldi Cesílo (Tatico) became the third Congressman to be convicted by the STF but the first to be sentenced to prison, albeit soft core. The STF sentenced Tatico to seven years of a semi-open prison regime (at liberty by day, prison at night) for misappropriating income tax payments his firm had collected from employees.

65. On October 28, 2010, the STF convicted Deputy Natan Donadon, who had just been re-elected despite two convictions in the state courts of Rondônia and had resigned the day before the judgment to try to send the case back to Rondônia. The STF sentenced Donadon to thirteen years and four months in prison, initially in a closed regime.

66. Ação Cautelar 2.763 Rondônia, Dec. 16, 2010 (STF, Rep. Celso de Mello). The preliminary injunction suspended for one year a decision of the Superior Electoral Tribunal that had refused to register Donadon's candidacy for reelection because of the Law of the Clean Slate. Minister Celso de Mello relied upon an illogical constitutional provision which states that "no one shall be considered guilty until his criminal conviction has become final and nonappealable." ConsT. of 1988, supra note 6, art. 5 (LVII). 
In June 2010, a popular initiative led to the enactment of a controversial statute called the Law of the Clean Slate. ${ }^{67}$ This law prohibits any candidate from running for political office for eight years if he or she has been convicted of certain crimes. But this prohibition applies only if one of the following three criteria are met: (1) the conviction has become final and non-appealable, (2) the conviction was rendered by a collegiate tribunal, or (3) the candidate resigned a mandate to avoid its cancellation. ${ }^{68}$ Initially, the constitutionality of the Law of the Clean Slate as applied to the 2010 elections was upheld by a short-handed and evenly divided STF. ${ }^{69}$ However, on March 23, 2011, after appointment of a new minister, the STF reversed its earlier decision and, by a vote of 6-5, held that the Law of the Clean Slate could not constitutionally be applied to the 2010 elections because of the one-year delay rule set out in Article 16 of the Constitution. ${ }^{70}$

\section{Habeas Data}

Brazil was the first country in Latin America to create a procedural institution called habeas data to enable persons to know what information about them exists in data banks and to correct misinformation. ${ }^{71}$ The right of habeas data first appeared in Brazil's 1988 Brazilian Constitution in the following terms:

67. Complementary Law No. 135 of June 4,2010 . This law was only the second statute to result from a popular initiative.

68. The eight-year period of ineligibility runs from the date that the sentence is completed.

69. The issue originally came before the STF in an appeal taken by Joaquim Roriz, ex-governor of the Federal District. The STF, which had only ten members because of a retirement, deadlocked five-to-five. Roriz then withdrew his candidacy in favor of his wife. Noticias STF, Sept. 29, 2010, available at www.stf.jus.br/portal/cms/ verNoticiaDetalhe.asp?idConteudo. The same issue was then presented in RE 63.1102 brought by Jader Barbalho, whose election as a senator was cancelled by the Superior Electoral Tribunal for violation of the Clean Slate Law. After the same 5-5 tie, the STF, by a 7-3 vote, decided to break the tie by resorting to art. 205, sole paragraph, of its Internal Rules, which provides that the constitutionality of the statute should be upheld in case of a tie. Noticias STF, Oct. 28, 2010.

70. RE 633703, Dec. Mar. 23, 2011 STF en banc, Rep. Gilmar Mendes. Art. 16 of the Const. of 1988, supra note 6, as modified by Amendment No. 4 of Sept. 14, 1993, provides: "A law altering the electoral process shall enter into force on its publication date and shall not apply to elections that occur within one year from the date it enters into force."

71. Although not called habeas data, similar remedies were created in Article 35 of the Portuguese Constitution of 1976, Article 105(b) of the Spanish Constitution of 1978, the U.S. Freedom of Information Act of 1974, and the French Law on Informatics and Liberties of January 6, 1978. Arnoldo Wald, O Habeas Data na Lei 9.507/97, in Habeas Data 13 (Teresa Arruda Alvim Wambier ed., 1998). 
Art. 5 LXXII- habeas data shall be granted:

a) to assure knowledge of personal information about the petitioner contained in records or data banks of government agencies or entities of public character;

b) to correct data whenever the petitioner prefers not to do so through confidential or administrative proceedings[.]

In the draft version of the Constitution, habeas data could be brought only by Brazilian citizens, and the writ could be used against both private and public data banks. In the final version, the limitation to citizens was deleted, as was the application of habeas data to private data banks. ${ }^{72}$ Congress did not enact a statute regulating habeas data until 1997. In the interim, lawyers and courts utilized the procedure enacted for the writ of security (see section IV infra)..$^{73}$

The 1997 statute implementing the writ of habeas data confers the additional remedy of adding an annotation stating that certain personal data is under dispute. ${ }^{74}$ This statute also made clear that an entity with a register or data bank is public in character if the data is being transmitted or could be transmitted to third parties. ${ }^{75}$ Habeas data actions have priority over all other actions with the exception of habeas corpus and writs of security. ${ }^{76}$ Yet habeas data may be brought only by persons with a direct interest in the challenged records or data banks, which means that it cannot be used to try to find the whereabouts of relatives or friends who disappeared during the military dictatorship or by journalists seeking access to facts the government prefers to keep secret. Because it is a summary procedure without an opportunity for resolving factual disputes, the writ of habeas data only applies to situations where a petitioner can attach documentary proof to his petition showing the plain incorrectness of the record or data or where there is no real factual dispute about the inaccuracy. If there is a serious dispute of fact, the writ of habeas

72. Caio Tácito, Judicial Control of Administrative Action in Brazil, in A PANOrama of Brazilian Law 27, 47 (Jacob Dolinger \& Keith S. Rosenn eds., 1992).

73. Law 8.038 of May 28,1990, art. 24, sole parargraph provides that until specific legislation is enacted, the courts should apply to the writ of habeas data the norms of the writ of security to the extent they are appropriate. Brazilian doctrinal writers and case law deemed the constitutional provision creating habeas data to be self-executing and used the procedures governing the writ of security. Cassio Scarpinella Bueno, Habeas Data-Efeitos da Apelação, Liminar e Suspensão de Sentença, in HABEAS DATA, supra note 71 , at $33,34-37$. The courts still resort to the norms governing the writ of security to fill lacunae in the 1997 implementing statute.

74. Law No. 9.507 of Nov. 12, 1997, art. 7(III).

75. Id. at art. 1. A data bank is not subject to habeas data if it is for the exclusive use of the entity that maintains it. Prior to Law 9.507, case law held that a private commercial association that publicly divulges information about debtors is subject to a habeas data action. Ap. 165.159-1/3, 686 REv. TRIB. 109 (2d Chamber, Tribunal of Justice of São Paulo, May 5, 1992, Rep. Costa de Oliveira).

76. Law No. 9.507, art. 19. 
data will not lie. ${ }^{77}$ Nor will habeas data lie unless the petitioner can show that the entity administrating the data bank refused a request to produce the contested data, ${ }^{78}$ refused to rectify or annotate it, or allowed fifteen days to pass without a response. ${ }^{79}$

In 1990, Brazil enacted the Code of Consumer Protection, ${ }^{80}$ which contains an article specifically granting consumers access to information about themselves in both private and public data banks. Article 43 of the Consumer Protection Code provides that without prejudice to the provisions of Article 86, the consumer shall have access to, and a right to correct any inaccuracies in, all personal and consumer information about him that is stored in commercial registries and data banks, as well as to sources of that information. Section 4 of Article 43 makes clear that "data banks and registries relating to consumers, credit protection and similar services are considered entities of public character." Unless solicited by the consumer, opening a file or register about a consumer must be communicated to him in writing, and registers or files of consumer data may not contain negative information dating back more than five years about the consumer. ${ }^{81}$ Article 86 originally provided that consumers could bring writs of security and habeas data to protect rights provided by the Consumer Protection Code. The President, however, vetoed Article 86 on the ground that:

The actions of the writ of security and habeas corpus are designed, by their nature, for defense of subjective public rights, and therefore, have as their principal objective acts of public agents. Their extension or application to other situations or legal relations is incompatible with their constitutional nature. ${ }^{82}$

77. Hely Lopes Meirelles, Arnoldo Wald \& Gilmar Ferreira Mendes, MANDADO DE SEGURANÇA E AÇÕES CONSTITUCIONAIS 305, n.5 (32d ed. 2009) [hereinafter Meirelles ET AL.].

78. Súmula No. 2 of the STJ provides: "Habeas data (CF, art. 5, LXXII, letter a) will not lie if there has not been a refusal of information on the part of the administrative authority." This case law rule, issued prior to the enactment of Law 9.507 of Nov. 12,1997 , is inconsistent with the statute.

79. Law 9.507 of Nov. 12,1997 , art. 8 (I,II, \& III). There are cases, however, that require the petitioner to prove that he or she has requested the data bank to produce, rectify or annotate the data. See Fernando Sacco Neto, O Habeas Data, a Súmula 2 do STJ e o Art. $8^{\circ}$, Parágrafo Único, I, II e III, da Lei 9.507/1997, in Processo e CONSTITUIÇÃO: ESTUDOS EM HOMENAGEM AO PROFESSOR JOSÉ CARLOS BARBOSA MOREIRA 41, 44-45 (Luiz Fux, Nelson Nery Jr. \& Teresa Arruda Alvim Wambier eds., 2006).

80. Law No. 8.078 of Sept. 11, 1990.

81. Section 5 of Article 43 prohibits credit protection systems from furnishing any information that might prevent or make more difficult new access to credit after the statute of limitations has run on collecting of a consumer debt.

82. Quoted in Eduardo Gabriel SaAd, Comentarios ao código de defesa do CONSUMIOR 664 (5th ed. 2002). 
Despite the presidential veto of Article 86, a substantial overlap exists between habeas data and the Consumer Protection Code.

In comparison with other constitutional writs, cases involving habeas data are seldom litigated. Most cases involving allegedly incorrect data are brought under the Consumer Protection Code against banks and credit agencies. These actions frequently utilize the procedure set out in Law 9.507, but unlike habeas data cases, the plaintiff can obtain both pecuniary and moral or non-pecuniary damages. ${ }^{83}$

\section{The Writ of Security}

To fill the gap left when habeas corpus was cut back to actual or threatened interference with locomotion, Brazil's 1934 Constitution created a new and broad constitutional remedy called the writ of security (mandado de segurança), often mistranslated as a writ of mandamus. The writ of security is a unique summary constitutional remedy that combines aspects of the Anglo-American writs of mandamus, injunction, prohibition and quo warranto, as well as the motion for summary judgment. The writ of security can be brought by an individual or legal entity to protect a "liquid and certain right" unprotected by habeas corpus or habeas data against actual or threatened illegality or abuse of power. Legal entity is a broad concept which includes even governmental entities, and like Mexican amparo actions, the writ of security action is sometimes brought by one governmental agency against another. The requirement that the right protected be "liquid and certain" means that the petitioner's right must be manifestly clear on the basis of documents attached to the petition, unless a needed document is in the hands of the respondent authority. ${ }^{84}$ Because it entails such a summary procedure, the writ of security will lie only when there is no need for an evidentiary hearing to determine the facts.

Unlike habeas corpus, the writ of security contains a state action requirement. The writ can only be brought against a public authority or an agent of a legal entity performing public duties. ${ }^{85}$ The new Writ of Security Law clarifies the public function concept by explicitly providing that "for the purposes of this Law, representatives or organs of political parties and administrators of autarchic entities, as well as directors of legal entities or individuals exercising governmental powers shall be equated with authorities, but only with respect to the

83. Code of Consumer Protection, art. 6 (VI); Rizzatto Nunes, Curso dE direito DO CONSUMIDOR 572-73 (3d ed. 2008).

84. MeIrelles ET AL., supra note 77, at 34-35; Mendes ET AL., supra note 5, at $533, \mathrm{n} .1$. If the respondent refuses to produce the needed document in its power, the judge will presume the necessary documental proof in favor of the petitioner. MEIRELLES ET AL., supra note 77 , at $35, \mathrm{n} .25$.

85. Const. OF 1988, supra note 6, art. 5(LXIX). 
exercise of such powers." 86 The writ of security has a preferential place on courts' dockets and a summary procedure. The action must filed within 120 days after the petitioner has knowledge of the challenged act in question. ${ }^{87}$ In cases of urgency, the petition can be transmitted by fax or other electronic communication, to be followed by a hard copy within five days. ${ }^{88}$ The authority has only ten days after service to render information to the court. ${ }^{89}$ If the authority wishes to present a defense, the matter will be sent to the Public Ministry, which must proffer its opinion within ten days, a period that may not be extended.90 After that time, the proceeding will be concluded regardless of whether the Public Ministry has rendered an opinion, and the judge has thirty days to render an opinion. ${ }^{91}$ In practice, however, the procedure is rarely this rapid but usually takes several months to be concluded. What is frequently critical in writ of security cases is the issuance of a preliminary injunction suspending the execution of the challenged act or procedure until the matter is ultimately decided. This preliminary injunction can be issued ex parte at any time to make the writ effective, but the judge has discretion to condition the injunction upon the petitioner's making a deposit with the court or posting a bond to indemnify the authority ${ }^{92}$ A preliminary injunction may not be issued against an order to pay taxes, to secure delivery of imported merchandise, reclassification or concession of salary increases or other advantages to civil servants. ${ }^{93}$

The writ of security also may not be used to challenge the constitutionality of a law unless the law is self-executing. ${ }^{94}$ Normally, one can challenge only the illegality or abuse of administrative actions implementing a statute. Nor can the writ of security be invoked to challenge an administrative act from which one may take an admin-

86. Law 12.016 of Aug. 7, 2009, art. $1 \S 1$. Brazil has a variety of public, private and mixed enterprises performing public services. An autarchy is an autonomous service, created by law, with its own legal personality, patrimony and income, to carry out a public service activity. Some perform commercial activities, such as the Federal Savings and Loan; some regulate commerce, and some control professional activities, like the Federal Bar. A public enterprise is a legal entity with its own patrimony and income, whose capital is entirely owned by the Federal Government or its indirect administrative entities. Such enterprises are created by law to carry out entrepreneurial activities of the government, such as telecommunications. Mixedeconomy companies are corporations for the exercise of commercial activity whose capital is partly public and partly private, but a majority of the voting shares is owned by the Federal Government either directly or indirectly.

87. Law No. 12.106 of 2009 , art. 23 .

88. Id. at art. 4.

89. Id. at art. 7(I).

90. Id. at art. 12 , heading.

91. Id. at art. 12, sole paragraph.

92. Id. at art. 7(III).

93. Id. at art. $7 \S 2$.

94. Súmula No. 266 of the Supreme Federal Tribunal provides: "The writ of security will not lie against a law in the abstract." See MEIRELLES ET AL., supra note 77, at 37 . 
istrative appeal that suspends enforcement of the act. And it may not be employed to challenge a final judicial decision from which one may take an appeal that suspends enforcement of the decision. 95 However, regardless of the availability of an appeal to a higher level in the hierarchy, the writ of security can be used to challenge omissions by an authority, provided the writ is brought within 120 days after judicial or extrajudicial notification of the omission. ${ }^{96}$

The 1988 Constitution created a collective writ of security, which combines the writ with a class action. Such a collective writ of security may be brought either by any political party represented in the National Congress or by any union, professional organization or legally organized association operative for at least one year to defend the liquid and certain rights of its members or associates. ${ }^{97}$ Not until 2009 , when it enacted a new Writ of Security Law, ${ }^{98}$ did Congress finally regulate the collective writ of security.

In general, the same procedures govern both the collective and the individual version. But the collective writ of security can also include both diffuse interests, such as the environment, and collective interests, such as determination of a wage increase for a category of civil servants. The filing of a collective writ of security does not prevent individual actions against the same authority and the effects of res judicata of the collective action do not affect the individual actions unless they were suspended pending the outcome of the collective proceedings. If it is successful, the collective action has res judicata effects that benefit only members of the class. If it fails, individual actions may later be brought against the same respondent. ${ }^{99}$

The writ of security is a widely used speedy check on governmental abuse of power or disregard for constitutional or legal provisions. It can function as a positive or negative injunction, compelling an authority either to perform or to cease performing an act. Moreover, the judge has the power to issue an ex parte preliminary injunction to preserve the status quo. Given the long delays associated with ordinary litigation, this preliminary injunction is frequently of critical importance. After a writ of security is granted, the norm may not be enforced against the party or group that filed the action. Non-parties, however, must bring their own actions if the authority persists in applying the controverted norm to them. The writ of security is a favorite device for challenging taxes and judicial decisions from which an appeal does not have a suspensive effect. In recent years, it

95. Law 12.016 of 2009 , art. 5 (I), (II) and (III).

96. Id. at art. 5 , sole paragraph.

97. Id. at art. 5(LXX).

98. Law 12.016 of Aug. 7, 2009. This statute revoked the prior Writ of Security Law, Law No. 1.533 of Dec. 31, 1951.

99. Eduardo Arruda Alvim, Mandado de segurança no direito tributário 387-88 (2d ed. 2010). 
has also become a popular means for enforcing one's constitutional right to health by securing a judicial order mandating that state or federal health agencies pay for the petitioners' HIV-AIDS drugs, expensive operations or unusual treatments. ${ }^{100}$

\section{The Mandate of InJunction}

Many rights created by the 1988 Constitution are not self-executing but require implementing legislation or regulations. ${ }^{101}$ Recognizing that legislative or bureaucratic inertia may create a serious obstacle to the protection of fundamental constitutional rights, the Congress that drafted the 1988 Constitution also created a new form of action called the mandate of injunction (mandado de injunção). This is somewhat of a misnomer because it has nothing to with the Anglo-American injunction. The Constitution provides that "the mandate of injunction shall be issued whenever lack of regulatory provisions makes the exercise of constitutional rights and liberties and prerogatives inherent in nationality, citizenship, or sovereignty infeasible." 102 The mandate of injunction is a form of action designed to goad Congress or regulatory agencies into acting, as well as to preserve constitutional rights until implementing legislation or regulations are adopted. It does not apply to all legislative or regulatory omissions, but is restricted to those that affect fundamental constitutional rights. ${ }^{103}$ It will not lie unless the time period set out in the Constitution for enactment of the necessary implementing legislation or regulation has expired. Moreover, enactment of the needed legislation will moot any pending mandate of injunction action. Even presentation of a bill containing the needed implementing legislation to Congress may prevent issuance of the mandate of injunction. ${ }^{104}$

100. The number of these cases has grown exponentially since 1991 . They are almost always successful and have had huge impacts on the health care budgets of the federal and state governments. See Octavio Luiz Motta Ferraz, Between Usurpation and Abdication? The Right to Health in the Courts of Brazil and South Africa, Aug. 20, 2009, http://ssrn.com/abstract=1458299; Octavio Luiz Motta Ferraz, Right to Health Litigation in Brazil, an Overview of the Research, May 15, 2009, http:// ssrn.com/abstract=1426011. The political backlash from this litigation has led to demands for legislation to curb the right to health litigation. It has also resulted in the STF's convoking a public forum in April and May 2009 to discuss what to do about the problem. The transcript of the debate is available at http:/www.stf.jus.br/portal/cms/ verTexto.asp?servico=processoAudienciaPublicaSaude.

101. According to the calculation of the Minister of Justice when the Constitution was promulgated, Congress needed to issue 285 ordinary laws and 41 complementary laws to effectuate constitutional provisions. Keith S. Rosenn, Brazil's New Constitution: An Exercise in Transient Constitutionalism for a Transitional Society, 38 Am. J. Comp. L.773, 778 (1990). The number of needed laws is actually greater because of the numerous amendments.

102. Const. OF 1988, supra note 6, art. 5 (LXXI).

103. Meirelles et al., supra note 77, at 289.

104. Dirley Da Cunha Júnior, Controle Judicial das omissóes do poder PúbLICO 537 (2d ed., 2008). However, in MI 361-RJ, D.J.U. June 17, 1994, p. 15.707 ( Rep. 
It is sheer irony that Congress has not yet enacted implementing legislation for the mandate of injunction. In 1989, the STF held that the constitutional provision establishing the mandate of injunction is self-executing, and that the procedural regime for the writ of security is applicable by analogy. ${ }^{105}$ The following year Congress endorsed the position taken by the STF. ${ }^{106}$ Like the writ of security, the mandate of injunction can be brought as a class action by the Public Ministry, any political party represented in Congress, union or syndical organization, or any legally constituted association to protect the interests of their members or associates. Unlike the writ of security, however, preliminary injunctive relief will not be granted in mandate of injunction actions. ${ }^{107}$ Nor can the mandate of injunction be used to challenge the constitutionality of legislation.

Brazil's highest court has struggled with the question of what should be the appropriate remedy in mandate of injunction cases. In 1990 , in what is usually termed the "leading case" on the subject, the STF took the position that the principle of separation of powers prevented the courts from supplying the needed implementing legislation or regulation as well as from ordering another branch of government to supply it. The only relief that could be granted was to warn the legislative body that it was not in compliance with the constitutional requirement, ${ }^{108}$ a position that rendered the mandate of injunction virtually useless if the legislature persisted in its inaction.

In 1991, for the first time in a mandate of injunction action, the STF gave Congress a specific time period to enact the legislation needed to make a constitutional right effective. Article $8 \S 3$ of the Transitional Constitutional Provisions Act provides that reparations shall be granted to all citizens prevented from practicing professions by resolutions adopted by the military government in accordance with a law adopted by Congress within one year after the Constitution went into force. When Congress failed to enact the necessary legislation, citizens who suffered damages from the military's actions filed mandate of injunction actions. The STF gave Congress a period of forty-five days in which to enact the needed law, plus fifteen days for the necessary presidential signature. ${ }^{109}$ When Congress ignored

Sepúlveda Pertence), the STF permitted the mandate of injunction even though a bill providing the implementing legislation was pending in Congress.

105. MI 107 QO-DF, Nov. 23, 1989 (133 R.T.J. 11 (1990)) (STF en banc, Rep. Moreira Alves).

106. Law 8.038 of May 28, 1990, art. 24, sole paragraph, provides that until specific legislation is enacted, the norms of the writ of security, to the extent appropriate, apply to the mandate of injunction.

107. MI 670/ES, D.J. May 24, 2002 (STF, Rep. Maurício Corrêa), stating: "The case law of this Court is firmly established in the sense that the nature of the mandate of injunction is incompatible with the concession of a preliminary injunction."(citing cases).

108. MI 107-DF, D.J.U. of Sept. 21, 1990 (STF, Rep. Moreira Alves).

109. MI 283, D.J.U. Nov. 14, 1991 (STF, Rep. Sepúlveda Pertence). 
the timetable, the STF permitted citizens injured by the military government to seek indemnification by ordinary damage actions without any further notification to Congress. ${ }^{110}$ Unfortunately, this solution means that the affected litigants had to wait for five years because of congressional inaction, but also that they will have to wait more than another five to ten years for the courts to resolve their constitutional claims through ordinary litigation, plus up to an additional ten years for the Federal Government to pay any judgment. But when charitable entities sought a tax exemption pursuant to Art. $195 \S 7$ of the Constitution, ${ }^{111}$ the STF held that if Congress failed to adopt the needed complementary law within six months, the petitioning charitable institutions would automatically receive the tax exemption. ${ }^{112}$

In 2007, the STF turned the mandate of injunction into a much more viable institution by overtly engaging in provisional legislation. Article 9 of the Constitution guarantees the right to strike, and $\S 1$ states that the law shall define which services or activities are essential and shall provide for meeting essential needs. Article 37 (VII) provides that the right to strike shall be exercised in the manner defined by a specific law. In 1989, Congress adopted a General Law on Strikes, which regulated the right of employees in the private sector to strike, including those employees providing essential services, but Congress failed to regulate specifically the right of civil servants to strike. ${ }^{113}$ In 1996 and 2002, the Supreme Federal Tribunal rejected mandate of injunction actions on behalf of civil servants to ensure their right to strike on the ground that specific legislation needed to be enacted. ${ }^{114}$ In 2007 , after nearly twenty years of Congressional procrastination, the STF decided that the time had come to fill the legislative vacuum on its own, albeit provisionally. That year the STF granted three mandates of injunction permitting civil servants to strike even though Congress had failed to enact the needed legislation. The Tribunal resolved the problem of the legislative omission by borrowing provisions of the General Law on Strikes, to the extent they fit, ignoring the lack of specific provisions applying to civil servants. ${ }^{115}$

110. MI No. 355, 200 R.D.A. 234 (1994) (STF, Rep. Celso de Mello).

111. Art. $195 \$ 7$ provides: "Charitable entities of social assistance complying with the requirements established by law are exempt from social security assessments."

112. MI No. 232, D.J.U. Mar. 27, 1992 (STF, Rep. Moreira Alves). Cf. MI No. 679, D.J.U. Dec. 17, 2002 (STF, Rep. Celso de Mello).

113. Law No. 7.783 of June $28,1989$.

114. MI No. 20, D.J.U. Nov. 22, 1996 (STF, Rep. Celso de Mello); MI 485, D.J.U. Aug. 23, 2002 (STF, Rep. Maurício Corrêa), and MI 585, D.J.U. Aug. 2, 2002 (STF, Rep. Ilmar Galvão).

115. MI No. 670-ES (Nov. 25, 2007) (STF en banc, Rep. Maurício Corrêa), 207 R.T.J. 11 (No. 1, 2009); MI No. 708, D.J.U. Nov. 25, 2007 (STF, Rep. Gilmar Mendes); MI No. 712, D.J.U. Oct. 25, 2007 (STF, Rep. Eros Grau). 
More recently, the STF continued on the same path in mandate of injunction actions brought to ensure rights to a special retirement regime for civil servants pursuant to Article $40 \S 4$ of the Constitution. Again, the exercise of this right required a complementary law that was never enacted. In a series of cases reflecting its new orientation, the STF granted mandates of injunction and ordered application of the special retirement provisions contained in Article 57 of the general Social Security Law, Law No. 8.213 of July 24, 1991, by analogy. ${ }^{116}$ The approach of the STF is similar to the familiar civil law technique of filling legislative lacunae by borrowing analogous statutory provisions. It does not manufacture the missing norm out of whole cloth but merely broadens the scope of an existing norm in order to ensure that constitutional rights can be enjoyed despite legislative inertia. It remains to be seen what will happen when there is no analogous norm to borrow.

\section{The Popular Action}

A creation of the 1934 Constitution, ${ }^{117}$ the popular action is a device that allows any Brazilian citizen to bring suit for the sole purpose of annulling acts or contracts injurious to the patrimony of any public entity. The action has no real standing requirements. It can be brought by any citizen merely in his capacity as a voter, regardless of whether he or she has any personal stake in the matter. Unlike other constitutional actions, the purpose of the action is to vindicate the collective interest in honest government and indemnification of losses to public patrimony rather than to vindicate individual rights and freedoms. The action must allege the illegality or illegitimacy of an act or contract, and that this impugned act or contract has caused injury to the public patrimony. ${ }^{118}$

In 1965 , the popular action was regulated by a statute that treats these suits as ordinary civil actions but with a more rigorous time frame. ${ }^{119}$ Once served, defendants have twenty days, renewable for a like period, in which to respond. Judges are obligated to file their decisions within fifteen days of receiving the documentary record. The statute tends to discourage popular actions by requiring plaintiffs to pay initial costs, the defendant's attorney's fees if the defendant prevails, and to pay ten times the costs of the suit if the action is deemed frivolous. ${ }^{120}$ The action must be brought within five

116. MI No. 755, decision of May 12, 2009, D.J.U. May 19, 2009 (STF, Rep. Eros Grau); MI No. 721, D.J.U. Nov. 30, 2007 (STF, Rep. Marco Aurélio); MI No. 758, D.J.U. Sept. 26, 2008 (STF, Rep. Marco Aurélio; MI No. 795, decision of Apr. 15, 2009, D.J.U. May 22, 2009, 210 R.T.J. 1070 (STF en banc, Rep. Cármen Lúcia).

117. CoNST. OF 1934, art. 113(38).

118. MeIRELLLES ET AL., supra note 77 , at 151.

119. Law No. 4.717 of June $29,1965$.

120. Id. at arts. 10 and 13. 
years from official publication of the challenged act. ${ }^{121}$ As in writ of security cases, preliminary injunctions can be issued here as well. ${ }^{122}$ Also like the writ of security, the popular action may not be used to challenge the constitutionality of a law in the abstract. ${ }^{123}$ It will, however, lie to challenge self-executing laws that have immediate consequences and are thus the functional equivalents of administrative acts, such as a statute that expropriates a specific property.

The 1988 Constitution expanded the popular action to include not only acts that injure the public patrimony, but also those that cause injury to administrative morality (i.e., corruption), the environment, and historic and cultural patrimony. ${ }^{124}$ The Public Ministry can bring a popular action, defend it, or assist the plaintiff, but in any case it must participate in the proceedings.

If the action is finally decided on the merits, the decision has erga omnes effect, whether the action is successful or not. This is because the decision becomes res judicata, and a similar popular action cannot be brought by another citizen. Only if it fails for insufficient proof may another popular action be brought on similar facts. ${ }^{125}$

\section{The Public Civil Action}

In 1985, Brazil enacted a statute that created a class action called the public civil action. ${ }^{126}$ Originally, the public civil action could be brought for damages caused to the environment, consumers, historic or artistic property or rights, and any other diffuse or collective rights. Subsequent legislation has extended its scope to include a wide range of diffuse and collective interests, such as violations of the laws protecting the economic order and popular economy, consumer protection, the handicapped, investors in the capital market, children, adolescents, the elderly, sports fans, and city planning. ${ }^{127}$ There is, therefore, considerable overlap with the popular action, and the two actions are sometimes filed together. But their aims are usually different. The popular action usually seeks to annul an act or contract, while the public civil action normally seeks a damage remedy or a remedy akin to a positive or negative injunction, namely that the defendant be required either to do something or to cease doing something.

121. Id. at art. 21.

122. Id. at art. $5 \S 4$, as amended by Law No. 6.513 of Dec. 20,1977 , art. 34 .

123. Meirelles ET AL., supra note 77 , at 160 .

124. Const. OF 1988, supra note 6 , art. 5(LXXIII), provides that any citizen may bring a popular action to annul an act injurious to the public patrimony, administrative morality, the environment, and to historic cultural patrimony.

125. Law No. 4.717 of June 29,1965 , art. 18.

126. Law No. 7.347 of July 24,1985 , as amended.

127. Id. at 184. MeIRELLES ET AL., supra note 77, at 184. 
The Brazilian public civil action differs in many important ways from the U.S. class action from which it was derived. First, individual members of the class cannot represent it. Second, the public civil action can only be brought by the Public Ministry, the Public Defender, the Federal Government, any state or municipal government, any governmental entity, foundation, or mixed-capital company, or any association, provided that its institutional purposes include protection of the diffuse or collective interests at stake and it has been in existence for at least one year. ${ }^{128}$ In practice, about ninety percent of all class actions are brought by the Public Ministry. Third, if it does not intervene in the action as a party, the Public Ministry must participate in the proceedings as the guardian of the law. Fourth, if the court awards a money judgment against the defendant, the award does not go to the class members. Instead, the proceeds of the judgment must be deposited in a Special Fund Account for Protection of Diffuse Rights. The funds are then used to restore rights violated by the defendant's conduct, often for funding research and educational projects. ${ }^{129}$ Fifth, the general rule that the prevailing party recovers costs and attorney's fees from the losing party is modified. On the one hand, losing plaintiffs need not pay costs or the other side's attorney's fees unless the action is brought in bad faith; on the other hand, if the defendant loses, it must pay plaintiff's costs and attorney's fees. ${ }^{130}$ Sixth, class members are notified only by publication. Even if they somehow manage to learn about the class action, they cannot opt out. They are free, however, to bring individual actions if the class action is unsuccessful, and, such individual actions can in fact go forward. ${ }^{131}$

The public civil action uses the procedure for an ordinary action and is governed by the Code of Civil Procedure. The judge can issue a preliminary injunction if requested in the complaint. Like the popular action, the judgment in a popular civil action has erga omnes effect in the sense that it constitutes res judicata with respect to any future class action unless there has been a failure of proof. But this res judicata effect is limited to the territorial jurisdiction of the court issuing the judgment. ${ }^{132}$.

Like the popular action, the public civil action will not lie to challenge the constitutionality of a law in the abstract. The public civil action has been widely used to protect the environment and consum-

128. Law No. 7.347 of 1985 , art. 5 .

129. Antonio Gidi, Class Actions in Brazil-A Model for Civil Law Countries, 51 AM. J. Comp. L. 311, 339-40 (2003). This is not true for consumer protection suits, where successful plaintiffs can recover individualized damages.

130. Id. at 340 .

131. Antonio Gidi, Rumo a um Código de PROCESSO CIVIL Coletivo: a CODificaÇão DAS AÇŌES COLETIVAS No BRAsIl 287-94 (2008).

132. Law No. 7.347 of 1985 , art. 16 . 
ers, and it is starting to be used to protect investors. Unfortunately, it cannot be invoked where it is most needed: to challenge the lawfulness of taxes, social security matters, the Fund for the Guarantee of Time of Service or other funds with named individual beneficiaries. ${ }^{133}$

\section{Making Inter Partes Decisions Binding ERga Omnes}

All six of the constitutional actions discussed above constitute parts of the system of incidental judicial review, and the decisions rendered in these cases normally have no binding effects beyond the parties. Nevertheless, unlike most other civil law countries, Brazil has developed four unique institutions designed to convert inter partes decisions into binding precedents.

\section{A. Senate Suspension}

The 1934 Constitution created a novel device for converting certain constitutional decisions of the STF into decisions that are binding erga omnes. ${ }^{134}$ This device, which is now embodied in Article 52(X) of the 1988 Constitution, grants the Federal Senate exclusive power "to suspend enforcement, in whole or in part, of laws declared unconstitutional by final decision of the Supreme Federal Tribunal." Whenever the STF has definitively determined that a federal, state or municipal law or norm is unconstitutional in a concrete case (diffuse or incidental judicial review), the President of the Tribunal sends a copy of the decision to the Federal Senate. The Senate then has the power to adopt a resolution suspending enforcement of the unconstitutional norm. ${ }^{135}$ Normally, the Senate issues the requested suspensory resolution. ${ }^{136}$ This neither repeals nor annuls the norm; it simply makes it unenforceable against anyone as of the date of

133. Id. art. 1, sole paragraph.

134. Const. of 1934, art. 91(IV).

135. Nelson Nery Junior, O Senado Federal e o Controle Concreto de Constitucionalidade de Leis e Atos Normativos: Separação de Poderes, Poder Legislativo e Interpretação da CF 52X, 47 REv. INFORM. LeGIS. 193, 194 (No. 187, Jy. /Sept. 2010). There is, however, some doctrinal support for the position that the Senate is required to suspend a norm definitively declared unconstitutional by the STF. Id. at 196, n.2; Regina Maria Macedo Nery Ferrari, Efeitos da declaração de inconstitucionALIDADE 201-04 (5th ed. 2004).

136. When the Senate refuses to suspend the unconstitutional norm, there is usually a rational explanation. For example, the Senate refused to suspend a federal statute requiring taxpayers to make contributions to the Fund for Social Investment (FINSOCIAL) because the STF's vote was only 6 to 5 , and because suspending this revenue measure would create a serious dent in federal finances. $R E$ 150.764-1, discussed in CLÈVE, supra note 7, at 276. 
adoption of the Senate's resolution. Once it has suspended the law, however, the Senate cannot revive it, either wholly or in part. ${ }^{137}$

Referral to the Federal Senate is unnecessary when the STF declares a norm unconstitutional in an abstract direct action or creates a súmula vinculante (see Section $\mathrm{C}$ below) because such decisions automatically have erga omnes effect. Lately, there has been a doctrinal debate as to whether abstract judicial review and the development of binding precedents have turned the Senate referral device into an anachronism. ${ }^{138}$

\section{B. The Súmula}

In 1964, the STF created a form of judicial precedent called the súmula (derived from the Latin noun summula, meaning little summary). The súmula is a collection of hundreds of capsulated rules of law that have become firmly settled by decisions of the STF. These numbered black letter rules are almost always only one sentence long, taken from the head notes to the STF's own decisions. Unlike common law precedents, however, these civil law precedents float freely from the facts of the cases in which they were determined. Rules are placed in the súmula only after the case law has become firmly established through a series of decisions, either through en banc uniformization or through a line of cases adopting a particular position.

The 1973 Code of Civil Procedure formally ensconced the súmula in positive law and assured that the other appellate courts would adopt their own súmulas. Article 479 of the Code of Civil Procedure provides that "a judgment rendered by a vote of an absolute majority of a tribunal's members shall be the object of the súmula and shall constitute a precedent for making the case law uniform." The sole paragraph of Article 479 directs each appellate tribunal to provide in its internal rules for the publication of its own súmula. If the lower court denies a request to file a special appeal to the STJ or an extraordinary appeal to the STF, that decision can still be appealed to the STJ or STF by a bill of review. If, however, the appealed decision conflicts with a súmula or predominant case law of the STJ, Article 544 of the Code of Civil Procedure (as amended by Law No. 9.756 of December 17,1998 ) authorizes the reporter, acting alone, to convert the bill of review into a special or extraordinary appeal and to adjudicate the merits. Article 557 of the Code of Civil Procedure (as amended by Law No. 9.756 of December 17, 1998) also gives the re-

137. RMS No. 16.512 (STF, Rep. Oswaldo Trigueiro), 38 R.T.J. 5 (1966), translated in Kenneth L. Karst \& Keith S. Rosenn, Law and Development in Latin America 119-24 (1975).

138. Compare Mendes et AL., supra note 5, at 1090, with Nelson Nery Junior, supra note 135. 
porter, acting alone, the power to deny an appeal that conflicts with the súmula or predominant case law of the STF or STJ or to grant an appeal against a decision that conflicts with the súmula or predominant case law of the STF or STJ. ${ }^{139}$

According to the Internal Rules of the STF, rules contained in its súmula can be adopted, modified or repealed only by vote of an absolute majority of the full Tribunal. ${ }^{140}$ The Internal Rules of the STJ state that its Súmula shall consist of decisions made by an absolute majority of the Special Court or one of the Sections in a procedure to make the case law uniform, as well as unanimous decisions of the Special Court or its Sections, or by an absolute majority in at least two concordant judgments. Modification or revocation of a sumula requires the vote of an absolute majority of the Special Court or its Sections, with a minimum of two-thirds of its members present. ${ }^{141}$ The most recent súmula of the STF is numbered 736 and was added in November 2003. The STJ, which has been in existence only since 1988 , has been creating súmulas more rapidly than the STF. Its most recent súmula is numbered 471 and was promulgated on February 23,2011 . Moreover, the number of súmulas actually in force today in the STF is fewer than 736 because some have been overruled, modified, or rendered obsolete, although the numeration remains the same. ${ }^{142}$ Normal practice is for the STF and STJ to dispose of appeals presenting the same legal issue summarily by simply citing to their súmulas. While technically the lower courts are not bound to follow a súmula, disregard of a súmula virtually ensures an automatic reversal.

\section{Binding Precedent (Súmula Vinculante)}

Constitutional Amendment No. 45 of 2004, known as the Judicial Reform Amendment, substantially reformed the Judiciary. One of the reforms was to permit the STF to create binding precedents in cases of incidental judicial review. The Amendment added to the Constitution a new article, which provides that after reiterated decisions on constitutional matters, the STF may, ex-officio or upon request, ap-

139. In both bills of review and appeals, the reporter's decision can be appealed by bill of review to a panel of the STF or STJ Code of Civil Procedure, arts. 545 and 557 $\S 1$.

140. Regimento Interno do STF, art. $102 \S 1$ (2010).

141. Id., arts. $122 \S \S 1$ and 2 , and $125 \S 3$.

142. At least thirty-six of the STF's súmulas have been revoked or cancelled. Some have been revoked by the 1988 Constitution or subsequent legislation, some refer to the prior constitution or interpret legislation no longer in force, some have been cancelled by a later decision of the STF, and one has been effectively overturned by a later inconsistent súmula of the STJ. A complete list of the súmulas of the STF and the STJ can be found on their websites with citations to the cases upon the rules are based: http://www.stf.jus.br/ and http://www.stj.jus.br/. 
prove a binding precedent (súmula vinculante). ${ }^{143}$ Like the nonbinding súmulas, binding precedents are short capsulated black letter rules of law floating freely from the facts of the cases upon which they are based. These precedents are binding not only upon the entire judiciary, but also upon the federal, state, and county public administration.

The STF can create a binding precedent only with the concurrence of at least two-thirds of its members sitting en banc. Amendment 45 authorized the STF to create a binding precedent either ex officio or upon request by a person with standing to bring a direct action of unconstitutionality. ${ }^{144}$ The implementing legislation has expanded standing to propose issuance, revision or revocation of binding precedents to include Superior Tribunals; the Tribunals of Justice of the States, Territories, and the Federal District; Federal Regional Tribunals, Regional Labor Tribunals; Regional Electoral Tribunals; and Military Tribunals. ${ }^{145}$ In addition, a county may also have standing to propose issuance, revision or revocation of a binding precedent, but only incidentally, i.e., in the course of litigation in which it is a party. ${ }^{146}$

Binding precedents have immediate effects. By a two-thirds vote, however, the STF can restrict its effects or decide that the precedent shall go into effect at a later time. ${ }^{147}$ If any administrative act or judicial decision contravenes or fails to apply a súmula vinculante properly, a special appeal, called a reclamation, may be filed with the STF. If it grants the reclamation, the STF will annul the act or vacate the decision and determine what should be instituted in its place. ${ }^{148}$

The STF has been in no hurry to create súmulas vinculantes. The first binding precedent was not created until mid-2007. Since then, the STF has issued only thirty-two súmulas vinculantes. One of these, Súmula Vinculante No. 13, has been highly controversial because the STF bent the rules on creating binding precedents to fill a legislative vacuum. One day before issuing its binding precedent, the STF decided a declaratory action brought by the Association of Brazilian Magistrates with respect to the constitutionality of a resolution adopted in 2005 by the National Council of Justice. ${ }^{149}$ This resolution prohibited the much abused practice of nepotism in staffing positions within the federal and state judiciaries. It was attacked as a violation of the principle of separation of powers by invading the province of

143. Const. OF 1988, supra note 6 , art. 103A.

144. Constitutional Amendment 45 of Dec. 30, 2004, art. $2 \S 2$.

145. Law No. 11.417 of Dec. 19,2006 , art. 3(XI).

146. Id. at art. $3(\mathrm{XI}) \S 1$.

147. Id. at art. $3(\mathrm{XI}) \S 4$.

148. Id. at art. $7 \S 2$. A reclamation against an omission or act of the public administration can be granted only after exhaustion of administrative remedies. Id. at art. 7 $\S 1$.

149. National Council of Justice, Resolution No. 7 of Oct. 18, 2005. 
the legislature, as well as on federalism grounds because a federal entity was regulating the conduct of state judiciaries. In sustaining the constitutionality of the Council of Justice's Resolution, the STF relied upon the heading to Article 37 of the Constitution, which provides: "The direct or indirect public administration of any of the Branches of the Union, States, Federal District and Counties, shall obey the principles of legality, impersonality, morality, publicity and efficiency ..."150 The very next day, the STF filled a legislative vacuum on its own by issuing a sumula vinculante extending the National Council of Justice's prohibition of nepotism in the Judiciary to ban nepotism in all branches of the federal, state and county governments, including all direct and indirect public administration. The STF also banned so-called "crossed nepotism," a creative Brazilian nepotism bypass where officials reciprocally employ each other's relatives. ${ }^{151}$ Lacking an established line of precedents for this novel proposition, the STF cited several of its prior decisions upholding laws or state constitutional provisions banning nepotism, as well as this direct action of constitutionality banning nepotism in the Judiciary. None of the cited precedents, however, constitute reiterated decisions with respect to an identical constitutional question suited to support the STF's legislative creation in Súmula Vinculante No. 13.152 While banning of nepotism in all branches of Brazilian government is undoubtedly a desirable policy measure to increase administrative probity and morality and to reduce corruption, this legislative enactment by the STF does not fit comfortably with the objective for creation of binding precedents. ${ }^{153}$

\section{General Repercussions}

Historically, the STF has lacked a device similar to the U.S. Supreme Court's writ of certiorari to enable it to refuse to decide unimportant cases. Since adoption of the 1988 Constitution, which vastly expanded the number of constitutional rights and access to judicial review, the STF's caseload has become overwhelming,

150. ADC No. 12, Decision of Aug. 20, 2008, DJ Dec. 18, 2008 (STF Rep. Carlos Britto).

151. Súmula Vinculante No. 13 approved Aug. 21, 2008, DJ Aug. 29, 2008.

152. Anontion Moreira Maués, Problemas sobre Súmula E Culpa do Próprio STF, Consultor JuRf́ico (July 3, 2010), available at http://www.conjur.com.br/2010-jul03/culpa-problemas-sumula-nepotismo-proprio-stf?im.

153. Const. of 1988 , supra note 6 , art. 103-A $\S 1$ provides:

The objective of a binding precedent shall be the validity, interpretation and efficacy of determined norms, as to which there is presently controversy among judicial bodies and the public administration, causing serious legal insecurity and corresponding multiplication of cases about identical questions. 
exceeding 100,000 cases annually. ${ }^{154}$ In an attempt to provide the STF with a functional analog to certiorari, the Judicial Reform Amendment (Amendment 45 of 2004) created a new constitutional limitation on extraordinary appeals called "general repercussions." 155 This screening device began to be implemented by the STF only on May 3, 2007, the date it approved a change in its Internal Rules. ${ }^{156}$ Since then, the STF has required every litigant bringing an extraordinary appeal to the STF to show that the appeal presents a constitutional question with general repercussions as a prerequisite to having the appeal heard by the Tribunal. Whether an appeal presents general repercussions depends upon whether it presents economic, political, social or juridical questions that extend beyond the parameters of the specific case. ${ }^{157}$ Any appeal against a decision that contravenes a sumula or the predominating case law of the STF is conclusively deemed to present a general repercussion. ${ }^{158}$ While the U.S. Supreme Court requires an affirmative vote of at least four members to grant a writ of certiorari, the STF requires a negative vote of at least eight of its members to deny an extraordinary appeal because it lacks general repercussions. ${ }^{159}$ Unlike the writ of certiorari, which has no precedential value, the determination by the STF that an appeal does not have general repercussions constitutes a binding precedent with respect to all other appeals presenting identical issues. ${ }^{160}$ The STF has also amended its Internal Rules to extend

154. The number of cases decided by the STF increased from 16,313 in 1988 to a high of 159,522 in 2007 . In 2010 , the number of cases decided fell to 103,869: http:/ www.stf.jus.br/.

155. The extraordinary appeal (recurso extraordinário) is derived from the writ of error of the U.S. Judiciary Act of 1789 . The extraordinary appeal may be taken from decisions of the sole or last instance that are contrary to the Constitution, declare a treaty or federal law unconstitutional, upholds a law or act of local government challenged as unconstitutional, or upholds a local law challenged as conflicting with federal law. Const. OF 1988, supra note 6 , art. 102 (III) $\S 3$, which was added to art. 102 by Amendment 45 of Dec. 8, 2004, provides:

In order for the Tribunal to examine the admissibility of an extraordinary appeal, which may be rejected only by manifestation of two-thirds of its members, the appellant must demonstrate the general repercussions of the constitutional question argued in the case, as provided by law.

156. Emenda Regimental No. 21.

157. Code of Civil Procedure, art. 543-A § 1, as amended by Law No. 11.418 of Dec. $19,2006$.

158. Id. at art. 543-A § 3 .

159. If, however, four members of a five member chamber of the STF decide that an appeal presents general repercussions, that determination will be decisive, and there will be no consideration of the issue by the full STF. Id. at art. 543-A $\S 4$. On Dec. 1, 2010, the STF amended art. 323 of its Internal Rules to permit the President of the STF to act as reporter for all extraordinary appeals prior to the vote on general repercussions, a vote that can be taken electronically in cases involving settled STF case law. Noticias STF, Dec. 1, 2010, http://www.stf.jus.br/portal/cms/verNoticias Detalhe $\cdot$ asp?idConteudo=167315\&tip=UN .

160. Code of Civil Procedure, at art. 543-A \& 5. 
the requirement of general repercussions to interlocutory appeals presented by a bill of review (agravo de instrumento). ${ }^{161}$

The requirement of general repercussions has been instrumental in reducing substantially the number of extraordinary appeals and bills of review being heard by the Supreme Federal Tribunal. From 2007 to 2010 , the number of extraordinary appeals distributed to the STF fell by $86.4 \%$, while the number of bills of review declined by $56.4 \% .{ }^{162}$

These four procedural institutions have required qualification of the proposition that decisions rendered by Brazilian courts in decentralized judicial review affect only the parties. Brazil is clearly moving towards creation of a civil law version of stare decisis upon both direct and indirect review.

\section{Abstract Review and the Direct Action OF UNCONSTITUTIONALITY}

Under prior Brazilian constitutions, the STF had original and exclusive jurisdiction to decide an original action challenging in the abstract the constitutionality of federal or state laws or normative acts. This action was originally called a representation, and only the Procurator General of the Republic had standing to bring it. ${ }^{163}$ The 1988 Constitution renamed the representation as the "direct action of unconstitutionality" and significantly expanded the list of persons with standing to bring it. In addition to the Procurator General, this group of persons currently includes the President of the Republic, the Executive Committee of either house of Congress, the Executive Committee of the legislature of any state or the legislative chamber of the Federal District, the Governor of any state or the Federal District, the Federal Council of the Brazilian Bar Association, any

161. Emenda Regimental No. 24 of May 8, 2008; Emenda Regimental No. 27 of Nov. 28, 2008. Law No. 12.322 of Sept. 9, 2010, transformed a bill of review taken from a decision refusing to permit an extraordinary appeal from a separate appeal into a procedure that permits appellate review on the same record. The STF has created a new classification for such appeals, called an extraordinary appeal with a bill of review (recurso extraordinário com agravo-aRE). Noticias STF, Dec. 1, 2010, http:// www.stf.jus.br/portal/cms/verNoticiasDetalhe.asp?idConteudo=167315\&tip=UN.

162. The number of extraordinary appeals distributed fell from 49,708 in 2007 , to 21,531 in 2008 , to 8,348 in 2009 , and to 6,735 in 2010 . The number of bills of review fell from 56,909 in 2007 to 37,783 in 2008, to 24,301 in 2009, and to 24,801 in 2010. http://www.stf.jus.br/portal/cms/verTexto.asp?servico=estatistica\&pagina=

REAIProcesso.

163. No matter how blatant the unconstitutionality of a statute, no one could compel the Procurator General to bring a reclamation if he did not wish to do so. See Reclamação No. 849 (Mar. 10, 1971), 59 R.T.J. 333 (STF en banc, Rep. Adalício Nogueira). Under prior Constitutions, the President could dismiss the Procurator General at will. Under the present Constitution, the Procurator General, who must be a career member of the Public Ministry, is appointed for a two-year term by the President, who can remove him only with the consent of an absolute majority of the Senate. Const. OF 1988, supra note 6, art. $128 \S \S 1$ and 2. 
political party represented in the Federal Congress, and any syndical confederation or national class entity. ${ }^{164}$

In direct actions of unconstitutionality, the STF decides the constitutionality of a challenged law or normative act in the abstract. The legislation must already be in force. Unlike countries that follow the model of the French Constitutional Council, Brazil has no anticipatory or preventive judicial review with the exception of writ of security actions by members of Congress to challenge proposed constitutional amendments. ${ }^{165}$ The STF has refused to permit any form of direct action to test the constitutionality of draft legislation. ${ }^{166}$ Technically, there are no adverse parties in the direct action of unconstitutionality, and third parties cannot intervene. ${ }^{167}$ The plaintiffs have a right to be heard, and the Procurator General must take a position before the Tribunal. While the Procurator General is free to support or oppose the action, the Advocate General of the Union must defend the constitutionality of the challenged law or act. ${ }^{168}$ The STF has borrowed a page from the U.S. courts by allowing the filing of amicus curiae briefs, and a page from the German Constitutional Court by holding public hearings before deciding particularly controversial constitutional challenges. ${ }^{169}$

The STF sits en banc rather than in panels in all direct actions of unconstitutionality, and a minimum of eight ministers is required to vote on any such action. A minimum of six votes is required to declare a statute unconstitutional in a direct action. ${ }^{170} \mathrm{~A}$ direct action can be summarily dismissed if the reporter to whom the action is assigned determines that the action is frivolous. ${ }^{171}$

The STF may issue provisional remedies, such as a preliminary injunction, in direct actions of unconstitutionality. Unless the Tribunal is in recess, such remedies can be issued only by an absolute majority of the entire Tribunal. These provisional remedies have erga omnes effects and usually operate only prospectively, but the STF has the power to make them retroactive. ${ }^{172}$ Governmental officials charged with enforcing the challenged rule normally have five days to respond before issuance of a provisional remedy, but in cases of ex-

164. Id. at art. 103 (I)-(IX).

165. See supra note 10.

166. ADI No. 466-DF (STF, Apr. 3, 1991, Rep. Celso de Mello), DJU of May 10, 1991.

167. Law No. 9.868 of Nov. 10,1999 , art. 7.

168. Const. OF 1988, supra note 6, art. $103 \S 3$.

169. Law No. 9.868 of 1999 , art. $7 \S 2$ authorizes the reporter to permit manifestations by other organs and entities, considering the relevance of the matter and the representativeness of the advocates. This has provided the basis for acceptance of amicus curiae briefs and expert testimony. See Mendes ET AL., supra note 5, at 1124.

170. Law No. 9.868 of 1999, art. 23; STF Regimento Interno, arts. 143 and 173.

171. Law No. 9.868 of 1999 , art. 4. This dismissal may be appealed to the full Tribunal.

172. Id. at arts. $10-12$. 
ceptional urgency the STF can act immediately. The reporting judge normally hears from the Procurator General and the Advocate General within fifteen days. In cases of special significance to the social order and legal security, the reporter can speed up the process by submitting the action directly to the full Tribunal. In this case the Advocate General and the Procurator General must submit their positions within five days. ${ }^{173}$

The direct action of unconstitutionality is by far the most numerous of the four types of direct constitutional actions. Since inception in 1988 and May 31, 2011, 4,554 direct actions of unconstitutionality have been filed in the STF. The STF has reached a final decision in only 3,011 of the 4,554 direct actions on its docket. Slightly more than $31 \%$ of the direct actions have been successful, either in whole (739) or in part (198). The STF has issued a preliminary injunction, either in whole (223) or in part (67), in only about $8 \%$ of the 1,113 pending direct actions. Approximately $7.8 \%$ of the direct actions were dismissed for lack of standing. ${ }^{174}$ Syndical confederations and unions initiated 1,105 direct actions deemed to have standing, more than any other group. State Governors were in second place with 1,098 , followed by the Procurator General with 932 , political parties with 797, the Federal Council of the Bar Association with 199, the Executive Committees of state legislatures with 52, the President of the Republic with eight, only one by the Executive Committee of the Federal Senate, and none by the Executive Committee of the Federal Chamber of Deputies. ${ }^{175}$

With a few very important exceptions, most of the direct actions of unconstitutionality have dealt with fairly narrow and parochial questions. Many are disposed of on narrow technical grounds. Nevertheless, the direct action is a useful device for political parties who have lost in Congress, particularly if they are able to persuade the Tribunal to issue a preliminary injunction, which provides them with important leverage. Merely threatening a direct action of unconstitu-

173. Id. art. 12.

174. The great bulk of those dismissed for lack of standing were brought by groups failing the STF's test of thematic relevancy, which insists upon an objective link between the plaintiff's institutional duties and the challenged statute. This requirement is not utilized for direct actions brought by the Procurator General, the Bar Council, and political parties, all of which are deemed to have a generalized interest in constitutional government. Carlos Antonio de Almeida Melo, Algumas Questões Objetivas sobre Ação Direta de Inconstitucionalidade, 36 Rev. INFORM. LeGIS. 111, 117-18 (No. 142m Apr./Je. 1999).

175. Açôes Diretas de Inconstitucionalidade por Legitimado-1988 a 2011, available at $\mathrm{http}: / / \mathrm{www} . \mathrm{stf}$.jus.br/portal/cms/verTexto.asp?servico=estatistica\&pagina=adi Legitimado. 
tionality may inspire the majority to negotiate seriously with the smaller parties. ${ }^{176}$

\section{The Declaratory Action of Constitutionality}

The declaratory action of constitutionality was created by Constitutional Amendment No. 3 in 1993. It confers upon the STF the exclusive power to hear "actions declaring the constitutionality of federal laws or normative acts." Although it appears to be redundant with the direct action of unconstitutionality, this is not the case. The declaratory action of constitutionality was created to allow the federal government to resolve sensitive issues involving the constitutionality of federal law quickly and authoritatively in the STF. When Brazil embarked upon a privatization program during the early 1990 s, the world was treated to a judicial circus in which opponents of privatization managed to secure preliminary injunctions from lower courts located all over the country to block the auctions. As Professor Arnoldo Wald explained, the basic purpose of the declaratory action "is to avoid delay and contradictions with respect to constitutional questions of highest importance, which if not resolved rapidly, might lead to true legal chaos, prejudicing the national economy and the very development of the country."177

Initially, there were three important differences between the declaratory action and the direct action of unconstitutionality. Between 1993 and 2004, standing to bring the declaratory action was restricted to three types of federal officials: (1) the President of the Republic, (2) the Executive Committee of either house of Congress, or (3) the Procurator General. Article 1 of Constitutional Amendment No. 45 of 2004 eliminated this difference and expanded those with standing to bring a declaratory action of constitutionality to the same group of persons entitled to bring the direct action of unconstitutionality. The second difference is that a declaratory action can be brought only with respect to federal laws and normative acts. It may not be used for state and county legislation. The third difference is that the declaratory action is available only if there is a judicial controversy with respect to the law or act that is involved. ${ }^{178}$ This means that the complaint must show judicial decisions questioning the constitutionality of the federal law or act at issue rather than purely doctrinal disputes. ${ }^{179}$

176. Inocência Martíeres Coelho, Constitucionalidade/Inconstitucionalidade: uma Questão Política, REv. JURIDICA VIRTUAL, No. 13 (Je. 2000) at http:/l www.planato.gov.br/ccivil_03/revista/Rev-13/ques_politica.htm.

177. Arnoldo Wald, Alguns Aspectos da Ação Declaratória de Constitucionalidade, 76 Rev. Processo 7, 8-9 (Oct.-Dec. 1994).

178. Law No. 9.868 of 1999 , art. 14(III).

179. Mendes et AL., supra note 5, at 1131-32. 
Procedures are similar for both the direct action and the declaratory action. Both the Procurator General and the Advocate General must be heard, and amicus curiae briefs can be considered. Absolutely critical to the declaratory action is that the STF has the power to enjoin ongoing proceedings involving application of the norm whose constitutionality it is considering. ${ }^{180}$

The first declaratory action involved the constitutionality of the amendment that created it. In a prior direct action of unconstitutionality, the Association of Brazilian Magistrates contended that the declaratory action was unconstitutional because it suppressed the creativity of judges and violated fundamental guarantees to judicial access, due process, full defense, and the adversary system, as well as the separation of powers by making the STF a consultative organ for the Congress. Even though this action was dismissed for lack of standing, the STF responded seriously to those contentions in the first declaratory action it decided. This was a case in which the President and the Executive Committee of the Congress sought a declaration that a social security tax was constitutional. In a divided vote, the STF held that the declaratory action of constitutionality was itself constitutional. ${ }^{181}$

The declaratory action has been little used. In the eighteen years since its creation, only thirty declaratory actions have been filed before the STF, which has decided only seventeen of them. Only seven of these declaratory actions have been successful, in whole (6) or in part (1), and in only two of the seven pending actions has the STF granted a provisional injunction. ${ }^{182}$ The declaratory action has served, however, as an important device in the government's efforts to avert a 1998 fiscal crisis, caused by lower courts conceding expensive salary increases to civil servants through a recently created procedural institution called tutela anticipada, a form of provisional relief. In a declaratory action brought by the President of the Republic and the Executive Committees of both houses of Congress, the STF issued a provisional injunction that prohibited all courts in the country from granting anticipatory salary increases to civil servants based upon the alleged unconstitutionality of Law No. 9.494 of 1997. ${ }^{183}$ That preliminary injunction, issued in 1998 , was critical because it was not until 2008 that the STF eventually declared the contested statute constitutional. ${ }^{184}$

180. Id. at 1138 .

181. ADC No. 1, 157 R.T.J. 371 (Rep. Moreira Alves, STF 1993).

182. Ações Declaratórias de Constitucionalidade-1993 a 2011 [through May 31, 2011], available at $\mathrm{http}: / / \mathrm{www} . s t f . j u s . b r / p o r t a l / \mathrm{cms} /$ verTexto.asp?servico=estatistica\& pagina $=$ adc.

183. ADC No. 4, Decision of Feb. 11, 1998, DJ Feb. 13, 1998 (Rep. Celso de Mello, STF).

184. Id., Decision of Oct. 1, 2008, DJ Oct. 15, 2008. 


\section{Xi. Allegation of Disobedience of a Fundamental Precept}

The 1988 Constitution created still another form of direct action before the STF called an allegation of disobedience of a fundamental precept. ${ }^{185}$ Because the constitutional language creating the action calls for enactment of a complementary law, the STF refused to permit utilization of this direct action until Congress passed such a law. ${ }^{186}$ It took Congress a little more than eleven years to enact Law 9.882 , the complementary law that implements the allegation of disobedience of a fundamental precept. ${ }^{187}$ This statute makes the standing requirements for bringing an action for disobedience of a fundamental precept identical to those for bringing a direct action of unconstitutionality or declaratory action of constitutionality. ${ }^{188}$ The disobedience of a fundamental precept action will lie only if there is no other effective remedy. ${ }^{189}$ Unlike the other direct actions to challenge constitutionality, the disobedience of a fundamental precept action may be brought to contest the validity of a law or other normative act that predates the 1988 Constitution. ${ }^{190}$ This fills a lacuna left by the case law of the STF holding that the direct action of unconstitutionality cannot be used to challenge the validity of legislation that predates the present Constitution. ${ }^{191}$

The regulatory law imposes a state action requirement, limiting use of the disobedience of a fundamental precept to avoiding or repairing injury to a fundamental precept resulting from a governmental act. ${ }^{192}$ As originally enacted, the regulatory law would have created full scale anticipatory judicial review for the first time in Brazilian history by allowing the action for disobedience of a fundamental precept to be used to annul proposed legislation. Such provisions were removed by Presidential veto. ${ }^{193}$ As currently enacted, the regulatory law grants an absolute majority of the STF the power to issue a provisional remedy suspending proceedings in any case before the lower courts unless the matter is res judicata. ${ }^{194}$

185. Const. OF 1988, supra note 6 , art. $102 \S 1$ provides: "Allegation of a disobedience of a fundamental precept stemming from this Constitution shall be heard by the Supreme Federal Tribunal, as provided by law."

186. Dirley da Cunha Júnior, Arguição de Descumprimento de Preceito Fundamanetal, in Açóes ConstitucionaIs, supra note 44, at 491, 492, n.2.

187. Law No. 9.882 of Dec. 3, 1999.

188. Id. at art. 2. Art. 2(II) as originally enacted also conferred standing upon "any person injured or threatened by an act of the Government." The President vetoed this provision because of concern about the STF being swamped with direct actions brought by individuals and its incompatibility with a system of abstract control of constitutionality. "Razões do Veto Presidencial," in Meirelles et Al., supra note 77, at $883,885-86$.

189. Law No. 9.882 , art. $4 \S 1$.

190. Id. at art. $1(\mathrm{I})$.

191. ADI No. 2, (STF Feb. 6, 1992, Rep. Paulo Brossard), DJU Nov. 21, 1997.

192. Law No. 9.882 of 1999 , at art. 1.

193. "Razões do Veto Presidencial," supra note 188, at 883, 884-85.

194. Law No. 9.882 of 1999 , art. $5 \S 3$. 
This innovative attempt to combine direct review with incidental review was quickly challenged in a direct action of unconstitutionality brought by the Federal Council of the Brazilian Bar Association. The Reporter in this case, Minister Néri da Silveira, determined that a constitutional amendment rather than a statute was required to authorize this procedure and voted to grant a preliminary injunction suspending the efficacy of this measure. Resolution of this case and the efficacy of this preliminary injunction were interrupted by a request to review the record by Minister Pertence Sepúlveda, and as of June 20,2011 , this case has not yet been decided by the STF. ${ }^{195}$ Yet, nearly four years later, in a subsequent disobedience of a fundamental principle action, the full STF issued a preliminary injunction suspending all pending criminal actions involving abortion of a fetus with anencephaly pending final decision of the STF on the merits. ${ }^{196}$ Moreover, in another subsequent disobedience of a fundamental principle case, the STF rejected the argument of amicus curiae that the undecided action for declaration of unconstitutionality against Law 9.882 of 1999 constituted a reason to suspend a disobedience of a fundamental precept action and stated that Law 9.882, including Article $5 \S 3$, was in full force. ${ }^{197}$ These subsequent decisions strongly indicate that Minister Néri da Silveira's position with respect to the unconstitutionality of Article $5 \S 3$ of Law 9.882 has been implicitly rejected by a majority of the STF.

At least two-thirds of the STF must be present to decide the merits, and the STF can declare the law or normative act either constitutional or unconstitutional. The decision of the STF in the disobedience of a fundamental precept action is binding upon the entire judiciary and government administration.

Neither the constitutional provision nor the implementing statute define what constitutes a fundamental precept. The STF has adopted a case by case approach to determining what is a fundamental precept. According to the doctrine, fundamental precepts include the individual rights guaranteed in the 78 subparagraphs of Article 5 , the unchangeable provisions referred to in Article $60 \$ 4$ (federalism, periodic elections, separation of powers, and individual rights and guarantees), and the constitutional principles referred to in Article 34 whose breach authorizes the Federal Government to intervene in the States or Federal District. ${ }^{198}$

195. ADI No. 2.231 (STF Dec. 5, 2001, vote of Rep. Néri da Silveira), DJ of Dec. 17, 2001.

196. ADPF No. 54, decision of Apr. 27, 2005, D.J.U. Aug. 31, 2007 (STF en banc, Rep. Marco Aurélio). This case has yet to be decided on the merits.

197. APDF No. 33, Decision of Dec. 7, 2005, 199 R.T.J. 873, 877 (2007) (STF en banc, Rep. Gilmar Mendes).

198. Mendes ET AL., supra note 5, at 1165. 
The action for disobedience of a fundamental precept has not been much used, nor has it been very successful. As of May 31, 2011, a total of only 227 disobedience of fundamental precept actions have been distributed to before the STF. More than half of these actions have been brought by syndical confederations and unions (65) and political parties (64). Only four have granted in full on the merits, and another two were partially granted. Provisional relief was accorded in eight actions and denied in seven. The STF refused to hear 119 actions, and another 84 actions have yet to be decided. ${ }^{199}$

Probably, the most celebrated successful action for disobedience of a fundamental precept, which curiously was decided concurrently with a direct action of unconstitutionality, interpreted Article 1723 of the Civil Code to recognize a civil union between same sex persons even though the text referred only to a union "between a man and woman." The STF unanimously held Article III(IV) of the Constitution, which states that a fundamental objective of Brazil is "to promote the well-being of all, without prejudice as to origin, race, sex, color, age or any other forms of discrimination," is broad enough to encompass discrimination on the basis of sexual preference, and that the statute should therefore be read to include same sex unions. ${ }^{200}$ The effect of this decision is to confer a broad range of benefits upon same sex couples.

\section{ACtion of UnCONSTITUTIONALITY FOR OMISSION}

The present Constitution confers original and exclusive jurisdiction on the STF to hear actions for unconstitutionality for omission whenever it determines the existence of the "lack of measures to make a constitutional rule effective."201 This action is the twin of the mandate of injunction in direct review form, and it presents similar problems. If the legislature has failed to adopt the needed implementing legislation, the STF notifies Congress of its omission. If the offender is an administrative agency, the STF may direct issuance of the needed regulation within thirty days.

Congress finally regulated the action of unconstitutionality for omission in 2009 by inserting a new chapter into the 1999 law that regulates the direct action of unconstitutionality and the declaratory

199. Arguição de Descumprimento de Preceito Fundamental Distribuidas-1993 a 2011 (through May 31, 2011), available at http://www.stf.jus.br/portal/cms/verTexto. asp?servico=estatistica\&pagina $=$ adpf.

200. ADPF 132 and ADI 4277 (STF en banc, May 5, 2011), Rep. Ayres Britto. ADI 4277 was originally protocoled as an action for disobedience of a fundamental precept, ADPF 178. "Supreme reconhece união homoafetiva,"Notícias STF, May 5, 2011.

201. Const. of 1988 , supra note 6 , art. $103 \S 2$. 
action of constitutionality. ${ }^{202}$ The standing requirements to bring the action for omission are precisely the same as for the direct action of unconstitutionality and declaratory action of unconstitutionality. ${ }^{203}$ The procedures governing the direct action of unconstitutionality apply to the action for omission when they fit. ${ }^{204}$ The reporter can request an opinion from the Advocate General. Unless he has brought the action, the Procurator General has fifteen days to review the proceedings. ${ }^{205}$ If there is exceptional urgency and relevance, an absolute majority of the full Tribunal can issue provisional measures, which may consist of the suspension of the law in a case of a partial omission. The provisional measure may also consist of suspension of judicial or administrative proceedings, or any other measure that the STF decides to impose. ${ }^{206}$

One of the most notable actions for omission in which the STF actually fashioned a remedy was an action brought by the Labor Party (PT) because of Congress' failure to issue a constitutionally mandated law that annually revised the salaries of federal government employees. The STF awarded damages to the employees based upon what they failed to earn had their salaries been adjusted by the general price index. ${ }^{207}$

Not surprisingly, the action for omission has not worked well. It is hard to know how many of such actions have been successful because until 2008, they were assigned the same classification as direct actions of unconstitutionality. Between 2008 and May 31, 2011, the STF has reached a final decision on only three actions for omission, none of which were successful. Ten more await decision. ${ }^{208}$

\section{Conclusions}

Brazil has developed a complicated hybrid system of judicial review that combines the centralized approach of European countries with the decentralized approach of the United States. It has also developed a broad array of constitutionalized procedural devices to try to turn constitutionally protected rights into reality. On paper, constitutional rights are incredibly well protected, and adequate procedural devices are in place for the judicial vindication of these

202. Law 12.063 of Oct. 27, 2009, inserted Chapter IIA into Law 9.868 of Nov. 10 , 1999 , in order to regulate specifically the direct action of unconstitutionality for omission.

203. Id. at art. 12-A.

204. Id. at art. 12-E.

205. Id. at art. 12-E $\S \S 2$ and 3.

206. Id. at art. 12-F.

207. ADI No. 2.061, Apr. 25, 2001, 179 R.T.J. 587 (2001) (STF en banc, Rep. Ilmar Galvão).

208. Ações Diretas de Inconstitucionalidade por Omissão-2008 a 2011 [through May 31, 2011], available at http://www.stf.jus.br/portal/cms/verTexto.asp?servico=estatistica\&pagina=ado. 
rights. Some constitutional rights are also well protected in practice; for example, freedom of speech and freedom of religion are widely respected. While there are still reports of threats and violence against journalists, the biggest threat to freedom of the press appears to come from the lower courts, which too often prohibit the media from reporting on investigations of political corruption because of privacy concerns. ${ }^{209}$ On the other hand, the STF has been actively protecting press freedom. In 2009 the STF declared unconstitutional the entire restrictive Press Law, enacted by the military regime in 1967 , and in 2010 suspended a law prohibiting satire of political candidates during the Electoral campaign. ${ }^{210}$ The right to health has been judicially protected in a great many cases, ${ }^{211}$ and Brazil has long had one of the world's best programs of free medical care for those suffering from HIV/AIDS.

Unfortunately, other constitutional rights, such as humane treatment in prisons, freedom from torture, the right to education, and the right to due process have not fared as well. Brazilian prisons are badly overcrowded and plagued by inhumane treatment and violence. Although the 1988 Constitution explicitly prohibits torture and makes commission of torture a non-bailable offense, ${ }^{212}$ severe mistreatment of criminal detainees remains a widespread practice. Extrajudicial killings by the police have been a chronic problem in Brazil, particularly in Rio de Janeiro, Salvador, and São Paulo. ${ }^{213}$ Illiteracy rates are still high in Brazil, especially in the Northeast, and there has relatively little success in the Brazilian courts with litigation seeking to enforce the constitutional right to education. ${ }^{214}$

Making paper rights a reality is only partly a task for the courts. It is more importantly a task for all levels of governments. Ultimately, what is required is a change in the culture of the elite with respect to the underprivileged and the marginalized.

209. U.S. Dept. of State, 2010 Human Rights Report: Brazil (Apr. 8, 2011), p. 8 [hereinafter 2010 Human Rts. Rep.], available at http://www.state.gov/g/drl/rls/hrrpt/ 2010/wha/154496.htm.

210. ADPF 130, STF en banc, Decision of Apr. 30, 2009 (Rep. Ayres Britto). In addition, in August 2010, the STF suspended a law prohibiting satire of political candidates. ADI 4.451, Sept. 2, 2010 (STF en banc, Rep. Ayres Britto).

211. Florian F. Hoffmann \& Fernando R.N.M. Bentes, Accountability for Social and Economic Rights in Brazil, in CourTing Social JustiCe: JUdiClal ENFORCEMENT of Social and Economic Rights in the Developing World 100, 116-20 (Varun Gauri \& Daniel M. Brinks eds., 2008).

212. Const. of 1988, supra note 6, art. 5(III) and (XLII). Law No. 9.455 of Apr. 7, 1997, specifically criminalizes torture and Decree No. 40 of Feb. 15, 1991 promulgates Brazil's adoption of the Convention against Torture and Other Cruel, Inhumane or Degrading Treatment and Practices.

213. Daniel M. Brinks, The Judicial Response to Police Killings in Latin America: INEQUality aND tHE RULE of LAW 45-47, 142-77, 223-41 (2008); 2010 Human Rts. Rep., supra note 210 , at 1.

214. See Hoffman \& Bentes, supra note 211. 
The 1988 Constitution has generated an enormous amount of litigation that has overwhelmed the Brazilian courts. While the STF, in contradistinction to most Brazilian courts, operates efficiently, managing to dispose of more than 100,000 cases a year, some of the most important and controversial constitutional questions, such as affirmative action, therapeutic abortion, and the constitutionality of a constitutional amendment adopted in 2000 that allows governmental entities to pay final judgments against them over a ten-year period have been sitting in the STF for many years without a final decision. The recent effort to reduce caseloads through binding precedents has not borne much fruit; however, the requirement of general repercussions as a device to curtail the number of appeals is starting to significantly reduce the exorbitant caseloads of the STF. The development of class actions is another step in the right direction. But the problem of long litigation delays still persists, along with the problem of inadequate representation of the poor and the indigent.

To further reduce the caseloads of Brazil's two highest courts, the current President of the STF, Cezar Peluso, has recently proposed adoption of a constitutional amendment that will allow execution of judgments even when they are subject to a special or extraordinary appeal. Noting that only about fifteen percent of such appeals to the Superior Tribunal of Justice and the STF are successful, Minister Peluso concludes that most are taken to delay execution of the judgment. By removing this incentive, the proposed amendment should sharply reduce the number of special and extraordinary appeals. Minister Peluso contends that adoption of his proposed amendment may make it possible to execute judgments ten to fifteen years earlier in many cases. ${ }^{215}$ This proposal has much to commend it and should be adopted.

The expansive array of rights protected by the Constitution, and the broad arsenal of constitutional remedies created to insure judicial enforcement have often forced the Brazilian courts into the political thicket without the ability to duck highly charged political questions. In a number of high profile cases, the STF has been overtly acting as a quasi-legislature and resolving an array of economic and political questions. ${ }^{216}$ The 1988 Constitution has forced the STF to become an activist court. This is partly because the Constitution attempts to circumscribe executive and legislative authority by constitutionalizing a

215. "PEC dos Recursos" é apresentada pelo presidente do STF e estará no III Pacto Republicano, Notícias STF, Mar. 21, 2011.

216. See Matthew M. Taylor, Judging Policy: Courts and Policy Reform in Democratic Brazil (2008); Oscar Vilhena Vieira, Supremocracia, 4 REv. de Direito 441 (No. 2, Jy.-Dec. 2008). Marcos Paulo Verissimo, A Constituição de 1988, Vinte Anos Depois: Suprema Corte e Ativismo Judicial "a Brasileira," 4 REv. DE DiREITo GV 407 (No. 2, Jy.-Dec. 2008); Diana Kapiszewski, Power Broker, Policy Maker, or Rights Protector? The Brazilian Supremo Tribunal Federal in Transition, in CouRTS IN LATIN AMERICA 154 (Gretchen Helmke \& Julio Rios-Figueroa eds., 2011). 
great many economic and social policy decisions. It also is because the framers of the Constitution intended to empower the STF as the guardian of the Constitution's structural constraints and the protector of a myriad of individual and group rights. As a result, the STF has been forced to determine how budgets should be allocated, whether wage increases for civil servants are required or permitted, whether presidents can reissue provisional measures that have the force of law for limited periods if Congress fails to ratify them, whether social security reform can have retroactive effects, or whether the Law of the Clean Slate can be applied to the current year's elections. Making these kinds of decisions has been a source of on going tensions with the political authorities and always creates a danger of political backlash. ${ }^{217}$ In the meantime, however, Brazil's federal courts have been playing a vital role in insuring that the constraints upon government set out in the 1988 Constitution are not merely words on paper.

217. The Judicial Reform Constitutional Amendment, adopted in December 2004, was a political manifestation of a widely felt need to make the Judiciary both more accountable and more efficient. 